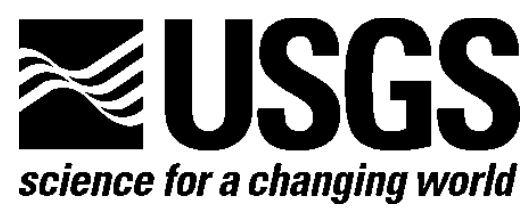

Prepared in cooperation with the Arizona Department of Environmental Quality

\title{
Predictive Models of the Hydrological Regime of Unregulated Streams in Arizona
}

By David W. Anning and John T.C. Parker

Open-File Report 2009-1269

U.S. Department of the Interior U.S. Geological Survey 


\section{U.S. Department of the Interior \\ KEN SALAZAR, Secretary}

\section{U.S. Geological Survey \\ Marcia McNutt, Director}

U.S. Geological Survey, Reston, Virginia 2009

For product and ordering information:

World Wide Web: http://www.usgs.gov/pubprod/

Telephone: 1-888-ASK-USGS

For more information on the USGS-the Federal source for science about the Earth, its natural and living resources, natural hazards, and the environment: World Wide Web: http://www.usgs.gov/

Telephone: 1-888-ASK-USGS

Suggested citation:

Anning, D.W., Parker, J.T.C., 2009, Predictive models of the hydrological regime of unregulated streams in Arizona: U.S. Geological Survey Open-File Report 2009-1269, 33 p. and spreadsheets.

[http://pubs.usgs.gov/of/2009/1269/.

Any use of trade, product, or firm names is for descriptive purposes only and does not imply endorsement by the U.S. Government.

Although this report is in the public domain, permission must be secured from the individual copyright owners to reproduce any copyrighted material contained within this report. 


\section{Contents}

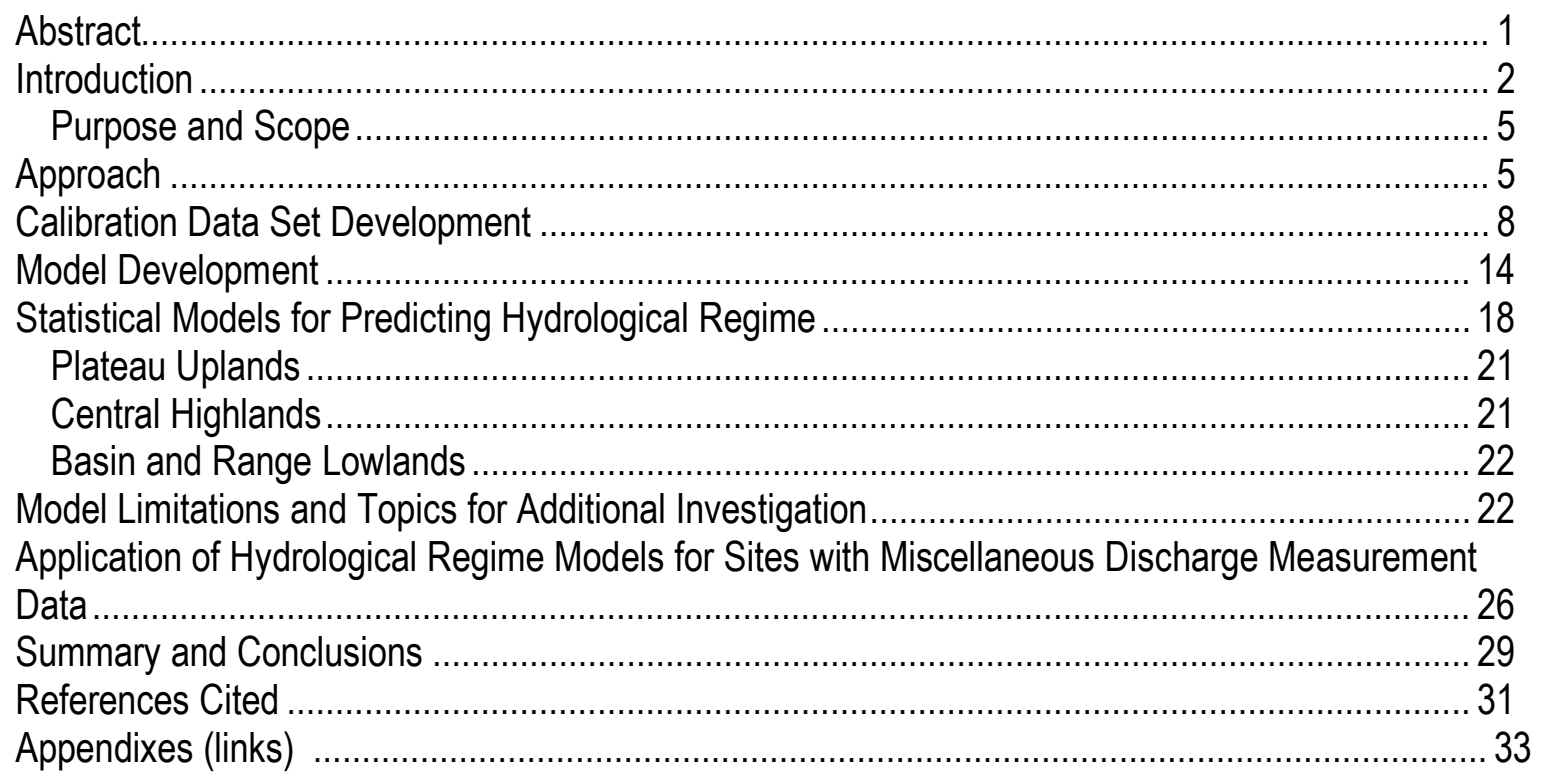

\section{Figures}

Figure 1. Arizona perennial streams as mapped by Arizona Game and Fish Department.

Figure 2. Percentage of years that are perennial, and average percent of year that discharge equals zero at streamflow-gaging stations in the Plateau Uplands, Central Highlands, and Basin and Range Lowlands hydrologic provinces in Arizona, 1950-2005.

Figure 3. Average percent of year with discharge greater than zero for streamflow-gaging stations used to calibrate the hydrological regime models for unregulated streams in Arizona.

Figure 4. Distribution of streamflow-gaging stations by years of discharge data available between 1950 and 2005 for A, the Plateau Uplands, B, the Central Highlands, and C, the Basin and Range Lowlands hydrologic provinces

Figure 5. Distribution of altitude and drainage area for streamflow-gaging stations in the Plateau Uplands, Central Highlands, and Basin and Range Lowlands hydrologic provinces ....

Figure 6. Example of recursive binary partitioning. A, shown geometrically; $B$, shown as a classification tree.

Figure 7. Residual deviance as a function of the number of regions in the hydrological regime classification tree for models determined using cost-complexity pruning for $A$, the Plateau Uplands, B, the Central Highlands, and C, the Basin and Range Lowlands hydrologic provinces

Figure 8. Hydrological regime classification tree for stream reaches in the Plateau Uplands hydrologic province.

Figure 9. Hydrological regime classification tree for stream reaches in the Central Highlands hydrologic province.

Figure 10. Hydrological regime classification tree for stream reaches in the Basin and Range Lowlands hydrologic province.

Figure 11. Predicted hydrological regime for sites with miscellaneous discharge measurement data available from the Arizona Department of Environmental Quality. 


\section{Tables}

Table 1. Misclassification matrices for the Plateau Uplands, Central Highlands, and Basin and Range Lowlands hydrological regime classification tree models

Table 2. Summary of predictions for sites with miscellaneous discharge measurement data available from the Arizona Department of Environmental Quality.

Appendix 1. Summary of location, basin, and hydrological-regime characteristics for U.S.

Geological Survey streamflow-gaging stations in Arizona and parts of adjacent states that were used to calibrate the hydrological-regime models

Appendix 2. Summary of location and basin characteristics for sites at which discharge measurements are available from the Arizona Department of Environmental Quality

Appendix 3. Model input and model predictions for hydrological regime of sites at which discharge measurements are available from the Arizona Department of Environmental Quality...

Appendix 4. Summary of model predictions for hydrological regime of sites at which discharge measurements are available from the Arizona Department of Environmental Quality

\section{Conversion Factors}

\begin{tabular}{|l|c|l|}
\hline \multicolumn{1}{|c|}{ Multiply } & \multicolumn{1}{|c|}{ By } & \multicolumn{1}{c|}{ To obtain } \\
\hline \multicolumn{3}{|c|}{ Length } \\
\hline foot $(\mathrm{ft})$ & 0.3048 & meter $(\mathrm{m})$ \\
\hline mile (mi) & 1.609 & kilometer $(\mathrm{km})$ \\
\hline \multicolumn{3}{|c|}{ Area } \\
\hline square mile $\left(\mathrm{mi}^{2}\right)$ & 259.0 & hectare (ha) \\
\hline square mile $\left(\mathrm{mi}^{2}\right)$ & 2.590 & square kilometer $\left(\mathrm{km}^{2}\right)$ \\
\hline \multicolumn{3}{|c|}{ Flow rate } \\
\hline cubic foot per second $\left(\mathrm{ft}^{3} / \mathrm{s}\right)$ & 0.02832 & cubic meter per second $\left(\mathrm{m}^{3} / \mathrm{s}\right)$ \\
\hline
\end{tabular}

Vertical coordinate information is referenced to the North American Vertical Datum of 1929 (NAVD 29).

Altitude, as used in this report, refers to distance above the vertical datum. Horizontal coordinate information is referenced to the North American Datum of 1927 (NAD 27). 


\title{
Predictive Models of the Hydrological Regime of Unregulated Streams in Arizona
}

\author{
By David W. Anning and John T.C. Parker
}

\begin{abstract}
Three statistical models were developed by the U.S. Geological Survey in cooperation with the Arizona Department of Environmental Quality to improve the predictability of flow occurrence in unregulated streams throughout Arizona. The models can be used to predict the probabilities of the hydrological regime being one of four categories developed by this investigation: perennial, which has streamflow year-round; nearly perennial, which has streamflow 90 to 99.9 percent of the year; weakly perennial, which has streamflow 80 to 90 percent of the year; or nonperennial, which has streamflow less than 80 percent of the year. The models were developed to assist the Arizona Department of Environmental Quality in selecting sites for participation in the U.S. Environmental Protection Agency's Environmental Monitoring and Assessment Program.

One model was developed for each of the three hydrologic provinces in Arizona - the Plateau Uplands, the Central Highlands, and the Basin and Range Lowlands. The models for predicting the hydrological regime were calibrated using statistical methods and explanatory variables of discharge, drainage-area, altitude, and location data for selected U.S. Geological Survey streamflow-gaging stations and a climate index derived from annual precipitation data. Models were calibrated on the basis of streamflow data from 46 stations for the Plateau Uplands province, 82 stations for the Central Highlands province, and 90 stations for the Basin and Range Lowlands province.

The models were developed using classification trees that facilitated the analysis of mixed numeric and factor variables. In all three models, a threshold stream discharge was the initial variable to be considered within the classification tree and was the single most important explanatory variable. If a stream discharge value at a station was below the threshold, then the station record was determined as being nonperennial. If, however, the stream discharge was above the threshold, subsequent decisions were made according to the classification tree and explanatory variables to determine the hydrological regime of the reach as being perennial, nearly perennial, weakly perennial, or nonperennial. Using model calibration data, misclassification rates for each model were 17 percent for the Plateau Uplands, 15 percent for the Central Highlands, and 14 percent for the Basin and Range Lowlands models. The actual misclassification rate may be higher; however, the model has not been field verified for a full error assessment.
\end{abstract}


The calibrated models were used to classify stream reaches for which the Arizona Department of Environmental Quality had collected miscellaneous discharge measurements. A total of 5,080 measurements at 696 sites were routed through the appropriate classification tree to predict the hydrological regime of the reaches in which the measurements were made. The predictions resulted in classification of all stream reaches as perennial or nonperennial; no reaches were predicted as nearly perennial or weakly perennial. The percentages of sites predicted as being perennial and nonperennial, respectively, were 77 and 23 for the Plateau Uplands, 87 and 13 for the Central Highlands, and 76 and 24 for the Basin and Range Lowlands.

\section{Introduction}

Hydrological regime, the seasonal variation in streamflow persistence and volume (United Nations Educational, Scientific, and Cultural Organization, 2007), is a primary control on the extent, diversity, and quality of aquatic and riparian habitat in streams and rivers. Perennial streams in which surface water is present year round provide a reliable source of water that nourishes a more diverse habitat for fauna and flora than do intermittent and ephemeral streams that transport water in response to seasonal conditions, such as periods of snowmelt, or to individual storm events (Giller and Malmqvist, 1998). Hydrological regime also affects the dependability of water supplies for domestic, commercial and agricultural use.

Resource managers, regulators and researchers require knowledge of hydrological regime in a variety of settings; however, obtaining such information is not as straightforward as it might seem, particularly in areas of highly variable precipitation and streamflow, such as the southwestern United States. The Arizona Department of Environmental Quality (ADEQ) is participating in the U.S. Environmental Protection Agency (USEPA) Environmental Monitoring and Assessment Program (EMAP), a nationwide program to develop the tools necessary to monitor and assess the status and trends of national ecological resources (United States Environmental Protection Agency, 2007). The EMAP approach for comprehensive water-quality assessments across each state in the nation involves a randomized site-selection process (probability-based site selection) and standardized sampling and analytical methods. The sampling population from which sites are randomly selected comes from the channel reaches classified as perennial in the National Hydrology Dataset (NHD). The NHD is an updated version of the USEPA Reach File 3 (RF3) and the digital line graph hydrography files (U.S.

Geological Survey, 1999a). The ADEQ also uses the Arizona Game and Fish Department perennial streams map (fig. 1; Brown and others, 1981; Arizona State Land Department, 1993).

During the EMAP Western Pilot Project, however, shortcomings of the randomized site-selection method in Arizona were evident in the perennial streams error rate. A total of 384 stream reaches in Arizona identified as perennial from the RF3 and the Arizona Game and Fish Department perennial streams map (Arizona State Land Department, 1993) were randomly selected forthe project . Forty-seven of these reaches were sampled during the 5-year sampling period from 2000 to 2004. While conducting the study, many of the original 384 selections were found unsuitable for sampling because they were actually nonperennial (Robinson and others, 2006). The sampling occurred during a period of extreme drought in Arizona, and water years 2000 and 2002 were among the driest on record (Phillips and Thomas, 2005). The increased time and 
expense associated with inadvertently selecting nonperennial sites are undesirable and are obstacles to adopting EMAP methods by State agencies such as ADEQ. ADEQ is interested in finding ways to make the site-selection process more efficient before they can consider adopting the EMAP protocols.

Difficulties in determining the hydrological regime of stream channels on a statewide basis are aggravated by the imprecise definition of 'perennial,' which is stated as containing "water throughout the year, except for infrequent periods of extreme drought" (U.S. Geological Survey, 1999b). Also, the stream channel attributes in the databases have been derived from older sources, predominantly topographic maps, some dating back as far as the 1950s, and the attributes have not necessarily been field checked since they were included in the databases (U.S. Geological Survey, 2006).

In 2005, ADEQ asked the U.S. Geological Survey (USGS) to develop a method that would improve the ability to predict hydrological regime, in particular perennial stream flow, on the basis of miscellaneous discharge measurements. Many miscellaneous discharge measurements have been made over the years by ADEQ, and they have amassed a data set of about 12,000 measurements for about 900 sites. Most sites have less than 20 measurements. If the frequency and number of measurements were greater, such as daily to weekly measurements for a site, one could assess the hydrologic regime based on the number of measurements with zero flow. The small number and infrequent measurement of discharge at each site in the ADEQ data set, however, precludes use of this simple approach. Determining whether a stream is was perennial or not on the basis of two or three discharge measurements without any additional information could lead to erroneous results. Consequently, the USGS developed statistically based models to predict the hydrologic regime of a stream reach on the basis of (1) miscellaneous discharge measurements and (2) basin characteristics for the measurement site. Use of the basin characteristics in the models reduces the uncertainty of the hydrologic regime estimates. 




Figure 1. Arizona perennial streams as mapped by Arizona Game and Fish Department. 


\section{Purpose and Scope}

The purpose of this report is to document statistical models that can be used to predict the hydrological regime of stream reaches on the basis of miscellaneous discharge measurements and a limited number of basin characteristics. The models were developed for predicting the hydrological regime of unregulated stream reaches in Arizona, which meant that many reaches on the main stems of the Colorado, Gila, Salt, and Verde Rivers below large reservoirs were excluded. The models account for climatic variability and incorporate the possibility for streams to be perennial in wet years and nonperennial in dry years.

\section{Approach}

Daily discharge data from USGS streamflow-gaging stations provide information about streamflow conditions for the reach they represent in the NHD network and can be used directly to assess the hydrological regime of a stream reach. For most stations the discharge record indicates the hydrological regime is either clearly perennial-every year of record has no days of zero discharge — or clearly not perennial — every year of record has one or more days of zero discharge. In figure 2 these sites clustered in the upper left part (nonperennial) and in the lower right part (perennial) of each graph. In some cases, however, a station may have mostly years with perennial flow except in years of severe drought. These sites are horizontally dispersed in the lower and right parts of each graph in figure 2. Similarly, a site may have most years without perennial flow, except in years of exceptionally high precipitation. These sites are horizontally dispersed in the lower left parts of each graph in figure 2. Sites without perennial flow most years vary in the percentage of the year with zero flow, as shown by the sites vertically dispersed in the left part of each graph in figure 2. 


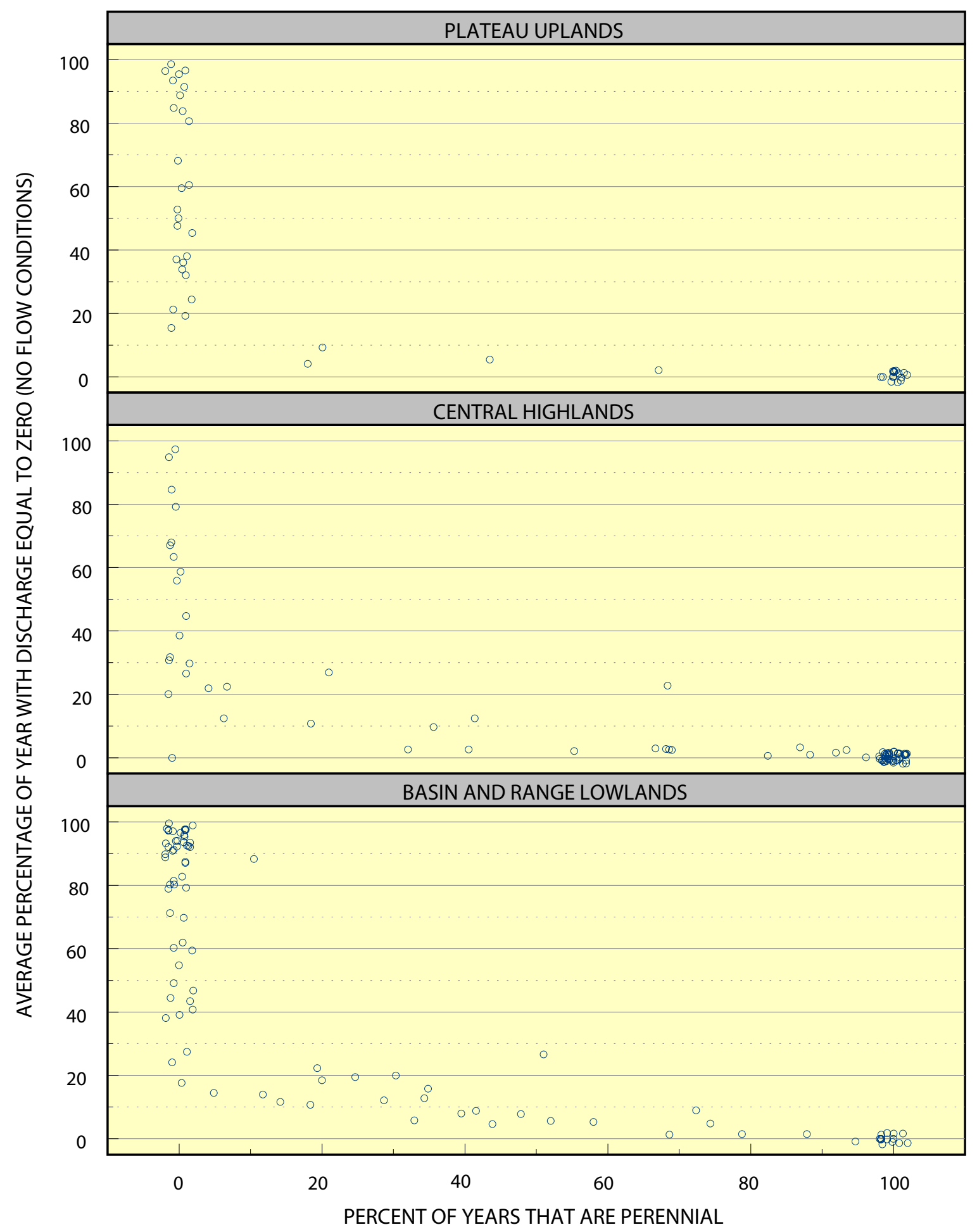

Figure 2. Percent of years that are perennial, and average percent of year that discharge equals zero at streamflow-gaging stations in the Plateau Uplands, Central Highlands, and Basin and Range Plateau Lowlands hydologic provinces in Arizona, 1950-2005. Note: each point represents one station; the number of years for each station varies. Where stations plot at the same location, points are moved slightly vertically and horizontally to distinguish individual stations. 
A classification scheme for hydrologic regime was developed as part of this study, where each class is thought to potentially support different assemblages of aquatic biota that have different tolerances and capabilities of surviving dry channel conditions: Perennial (P), which has no days of zero-discharge flow for the year of interest, Nearly perennial (NP1), which has zero-discharge flow on at least one day of the year, but not more than 10 percent of the year, Weakly perennial (NP2), which has zero-discharge flow between 10 and 20 percent of the year, and Nonperennial (NP3), which has zero-discharge flow more than 20 percent of the year.

The classes were derived from (1) examination of the distribution of the data and (2) expertise and professional judgment from staff at ADEQ on the significance that the number of zero-discharge days per year may have for aquatic biota. Because the hydrological regime is specific to a given year, this classification allows for sites to be perennial in some, but not all, years. Classifying stream reaches by these four hydrologic regimes would aide in selecting sampling reaches for the EMAP study and other aquatic ecology studies.

The stream reaches with USGS streamflow-gaging stations, however, only represent a small portion of the stream reaches in the NHD network (fig. 1). As part of its surface-water-quality sampling program, ADEQ has made about 12,000 discharge measurements on about 900 ungaged stream reaches. These data alone are not directly suitable for assessing the hydrological regime of stream reaches because each measurement only represents a single point in time during the year. To make the miscellaneous discharge data potentially useful for predicting the hydrological regime of a reach for a given year, a statistical model was developed with explanatory variables, such as the discharge magnitude $\left(\mathrm{ft}^{3} / \mathrm{s}\right)$, season (month), and climatic conditions for a miscellaneous discharge measurement, and a small number of basin characteristics. The statistical model was calibrated using USGS daily streamflow data from gages with at least one or more years of daily discharge values.

The rationale for selecting explanatory variables in the model is as follows: if a stream reach is observed to have zero flow during a miscellaneous discharge measurement, then it is not perennial. If, however, there is flow, then the reach might be perennial. The discharge magnitude, month of the measurement, and climatic conditions need to be considered in predicting the hydrological regime. For example, a stream reach with a discharge of $10 \mathrm{ft}^{3} / \mathrm{s}$ may have a higher likelihood of being perennial than a reach with only $1 \mathrm{ft}^{3} / \mathrm{s}$, if basin characteristics and other conditions are equal. Also, a stream reach with a measured discharge of $10 \mathrm{ft}^{3} / \mathrm{s}$ in June should have a higher likelihood of being perennial than a reach with the same discharge measured in January. In June, stream flows generally are near their minimum discharge for the year because of the long spring dry spell between the winter and summer rainy seasons and because evapotranspiration rates are high. Furthermore, discharge measurements that show the presence of stream flow during relatively dry years might indicate that a stream reach is more likely to be perennial than when such measurements are made in relatively wet years. Likewise, dry stream channels in wet years are more likely to be nonperennial than those that have zero discharge in dry years.

Basin characteristics, such as reach altitude, drainage area, and the general hydrogeology of the drainage basin contributing flow to the reach may also affect the 
hydrological regime of a stream reach, and should be considered in the model. For example, several of the perennial stream reaches depicted by Brown and others (1981; fig. 1) occur in small drainages at high altitudes.

Hydrogeology is one of the most important aspects affecting the hydrological regime of a stream; however, it is also the most difficult factor to represent because of a lack of data availability. Perennial reaches are dependent in part on (1) geologic controls that create impermeable barriers that impede groundwater flow and (2) aquifers with sufficient storage and recharge rates that can supply groundwater discharge to springs and stream beds year-round at rates higher than losses due to streambed infiltration and evapotranspiration. The complexity and variability of hydrogeologic factors, such as geologic structure and lithology, is too great to be represented in detail in a regional-scale model; therefore hydrogeology was generally represented by developing separate models for the three hydrologic provinces in Arizona (fig. 1; Arizona State Land Department, 1969). The Plateau Uplands hydrologic province is characterized by generally flat-lying or lightly deformed sedimentary and volcanic rocks. The province is affected by a wide range of climatic conditions and includes the wettest areas in the state as well as dry but cool areas; it contains substantial areas of both recharge and discharge (Hart and others, 2002). The Central Highlands hydrologic province includes more complexly deformed, fractured sedimentary and volcanic rocks, granitic intrusions, and Tertiary-Pleistocene basin fill deposits and is mainly a discharge area for the groundwater system of the Plateau (Parker and others, 2005). This province also contains most of the higher elevation drainages and perennial streams in the State. The Basin and Range Lowlands hydrologic province is formed by fault-block mountain ranges separated by Tertiary to Holocene basin fill deposits. In this province, groundwater recharge occurs through bedrock fractures and faults in mountains and through alluvial materials at the mountain front and losing stream reaches in the valleys; discharge occurs through bedrock fractures and faults in the mountains, and through alluvium in spatially interrupted gaining stream reaches in valleys (Anderson and others, 1992). Development of the three models allows the other variables in the model to have somewhat different effects on streamflow permanence in each hydrogeologic province by taking into account some fundamental hydrogeologic differences among the provinces.

\section{Calibration Data Set Development}

The hydrological-regime models were calibrated using data for reaches with USGS streamflow-gaging stations. The calibration dataset included (1) the response variable, which is the hydrological regime for the reach, and (2) explanatory variables, which included the reach discharge (explained below), month (season) for the reach discharge, a climate index for the year of the reach discharge, site altitude, and contributing drainage area for the reach.

Streamflow-gaging stations in Arizona that had daily discharge data since 1950 available from the National Water Information System (NWIS) were evaluated for use in the calibration data set. In addition, three stations in the Little Colorado River and Gila River drainages in western New Mexico were included in the calibration data set. Most sites with daily discharge data were included in the calibration data set; however, sites with certain qualities were excluded. Sites with less than one complete year of daily values were excluded because the hydrological regime of streamflow for the year(s) with data could not be assessed. Sites downstream from major reservoirs were excluded 
because of regulatory influences on streamflow occurrence and magnitude. Most of these excluded sites were on the Colorado, Gila, Salt, and Verde Rivers. Likewise, sites on canals, diversions, and streams on which flow is maintained by effluent or irrigation return flow were excluded. Stream reaches with flow affected by reservoir impoundment and releases or by irrigation return flows were determined from Brown and others (1981), and stream reaches with flow affected by municipal effluent were determined from Brown and others (1981) and State of Arizona (1996).

After evaluating stations on the basis of the above qualifications, 223 streamflowgaging stations were available for use in the calibration data set (fig. 3; appendix 1). For each station, the latitude, longitude, station altitude, drainage area, and hydrologic accounting unit were retrieved from the NWIS. Hydrologic accounting units are surfacewater basins that are identified by their 6-digit number and were defined as part of the USGS hydrologic unit system (Seaber and others, 1987), a nationwide set of nested hydrologic drainage boundaries. The latitude and longitude data and a digital representation of hydrologic province boundaries were used to determine in which hydrologic province the station is located. There were 46 stations with data in the Plateau Uplands province, 82 stations with data in the Central Highlands province, and 90 stations with data in the Basin and Range Lowlands Province. 


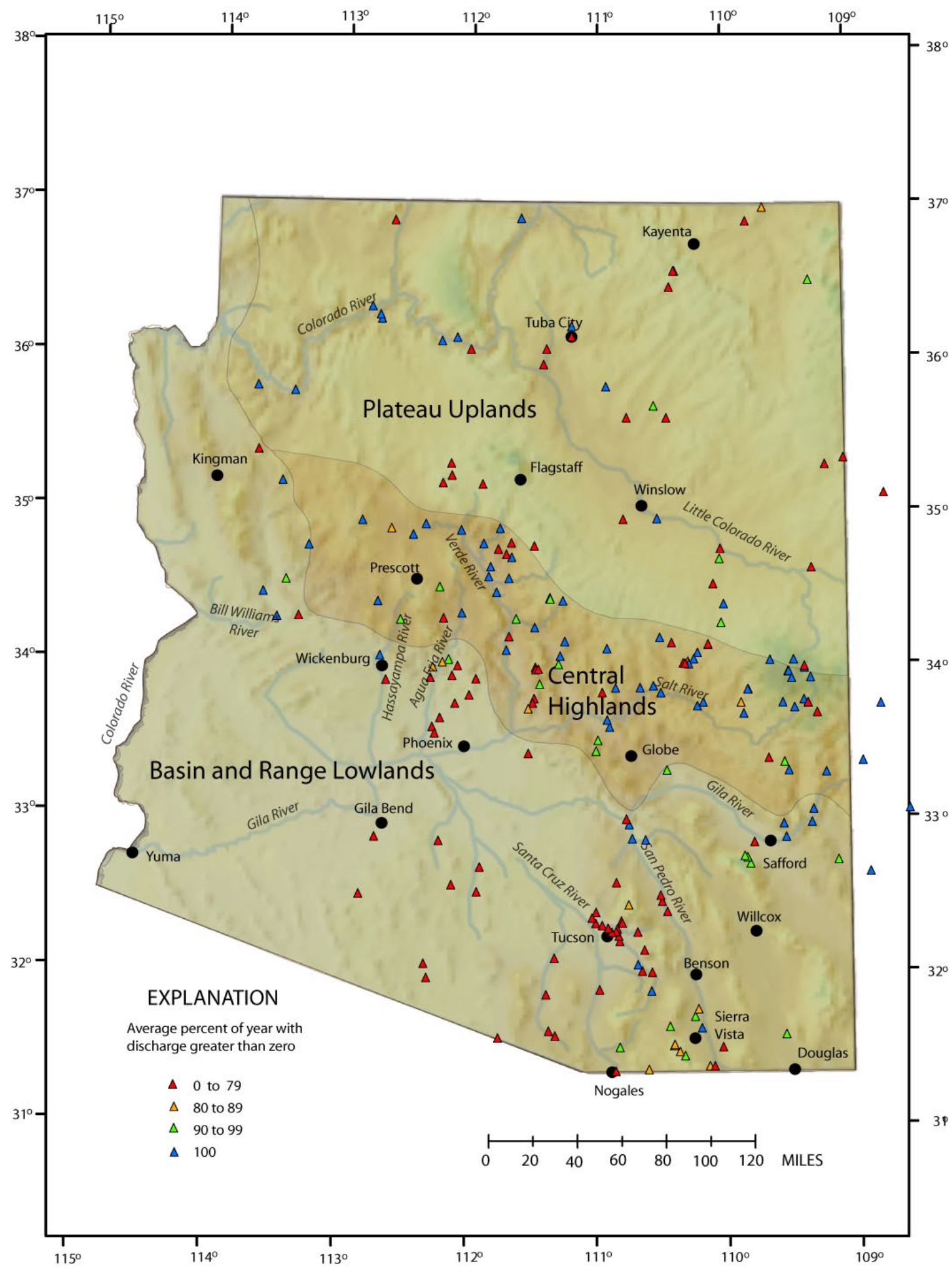

Figure 3. Average percent of year with discharge greater than zero for streamflowgaging stations used to calibrate the hydrological regime models for unregulated streams in Arizona. 
The number of complete years with daily discharge data available at streamflowgaging stations used in the study varies by station and is shown in figure 4 . For this investigation, "complete years" were defined as not missing any days of daily discharge values. For model calibration, each station ideally would have the same number of years of data so that conditions represented by each gage are represented equally. Including 55 years of discharge data for some sites and only a few years of data for other sites would bias the model calibration to largely represent those sites with 55 years of data and underrepresent those sites with only a few years of data. To avoid introducing such bias into the model, a maximum of 10 complete years of data for a given station were selected for use in constructing observations for the calibration data set. The years selected for each station were chosen by assigning each complete year a random number and then selecting the years with the 10 lowest random numbers. Ten was chosen subjectively as the maximum number of years to (1) minimize the number of stations that lack the maximum years of data, (2) have multiple years of data so that different climate conditions are represented for a given station, and (3) have a large enough number of observations available for calibrating the models. 

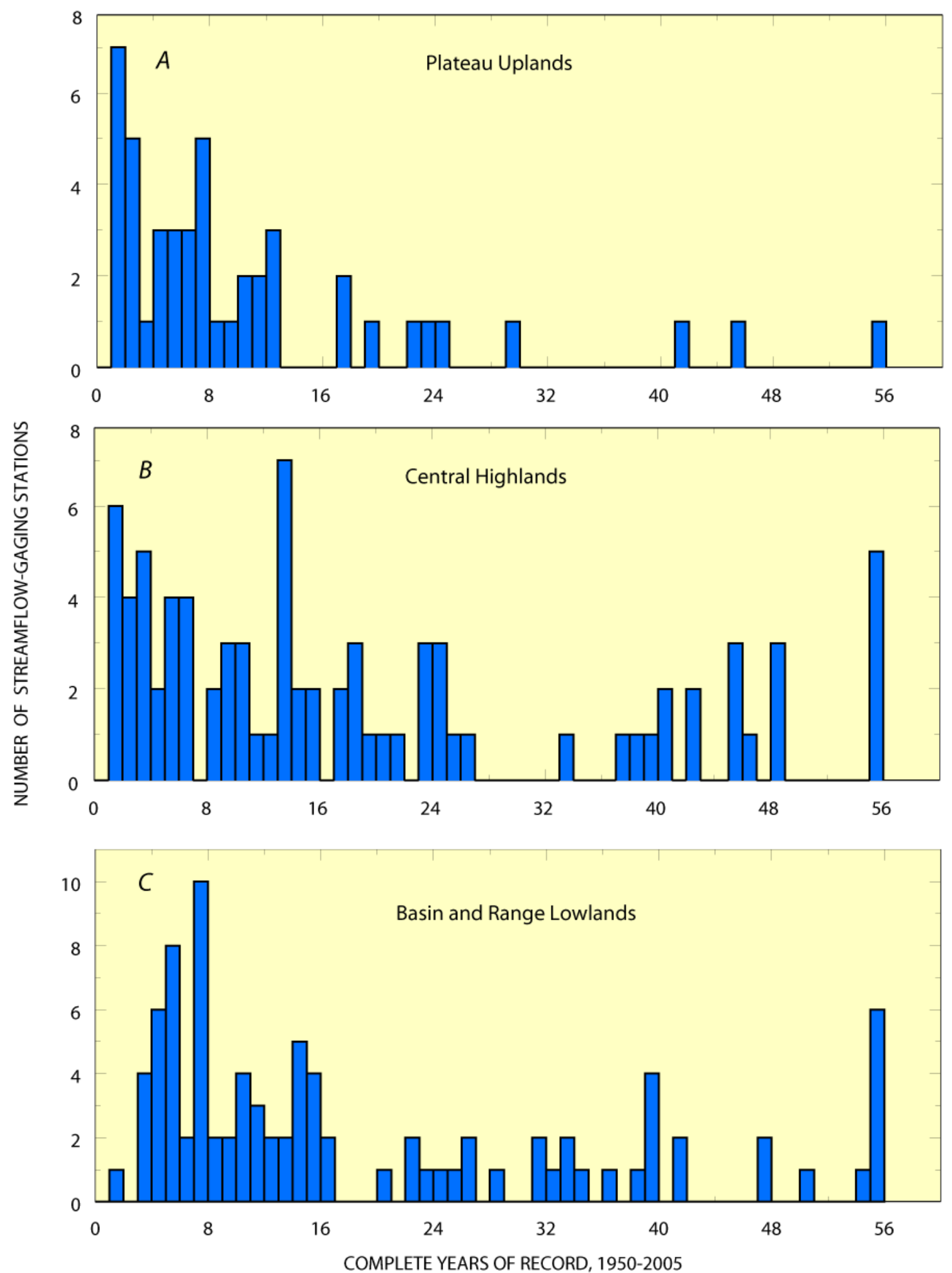

Figure 4. Distribution of streamflow-gaging stations by years of discharge data available between 1950 and 2005 for $A$, the Plateau Uplands, $B$, the Central Highlands, and $C$, the Basin and Range Lowlands hydrologic provinces. 
Daily discharge data were used to develop the hydrological-regime and reachdischarge data for each observation. For each complete year of data for each station, the percentage of the year with discharge equal to zero (no flow conditions) was computed. Then, for each complete year of data for each station, the hydrological regime of streamflow for that year was classified as being (1) perennial, (2) nearly perennial, (3) weakly perennial, or (4) nonperennial, as defined previously in the "Approach" section of this report.

The reach-discharge observations in the calibration data set need to be representative of flow conditions for the miscellaneous discharge measurements made by ADEQ. These discharge measurements were made as part of ADEQ's ambient surfacewater quality monitoring programs, and for the most part, with some exceptions, were collected during low-flow conditions. Therefore, reach discharge in the observation data set is populated with monthly minimum daily discharge values. For each complete year of data for each station, there are 12 different values for the reach discharge and 12 corresponding values for hydrological regime of the reach and other explanatory variables. Use of monthly data allowed the model to represent all periods throughout the year in which discharge could be observed. The month of the reach-discharge value was represented as a decimal fraction of the year and was computed for the middle day of the month represented by the minimum monthly value. For example, the numeric value for the month of the reach discharge represented by the minimum daily discharge is 0.0438 (16/365) for January, 0.123 (45/365) for February, and so forth.

Climate conditions for the reach discharge were represented by an index constructed using annual precipitation data from selected sites in the Historical Climatology Network (Williams and others, 2005). Climate indices were constructed to represent stream reaches in each accounting unit in Arizona and are specific to each year. The index for a given accounting unit was constructed by first selecting a precipitation gage that (1) is generally considered representative of climatic conditions for the unit and (2) has annual data available from 1950 through 2005. Next, the annual precipitation data were ranked and then divided by 56, which is the number of years of data. The result of these operations is an annual series of the accounting-unit specific climate index that range between 0 and 1 . Values greater than 0.50 represent relatively dry years, and values less than 0.50 represent relatively wet years. If data were missing for a particular year for an accounting unit, the average index value for the remaining accounting units for that year was used. Each observation in the calibration data set was assigned a climate index value on the basis of (1) the year of the reach discharge and (2) the accounting unit of the streamflow-gaging station.

The drainage area and altitude of the streamflow-gaging station which the reachdischarge data represent were added to each observation in the calibration data set (fig. 5). Altitude generally decreases from the Plateau Uplands to the Central Highlands to the Basin and Range, whereas basin drainage area generally increases along the same transect. If for any reason any values of the dependent or explanatory variables were missing for an observation during any of the steps in developing the calibration data set, then that observation was deleted. The final step of developing the calibration data set was to split it into 3 separate input files, each with stations representing one of the 3 different hydrologic provinces. 


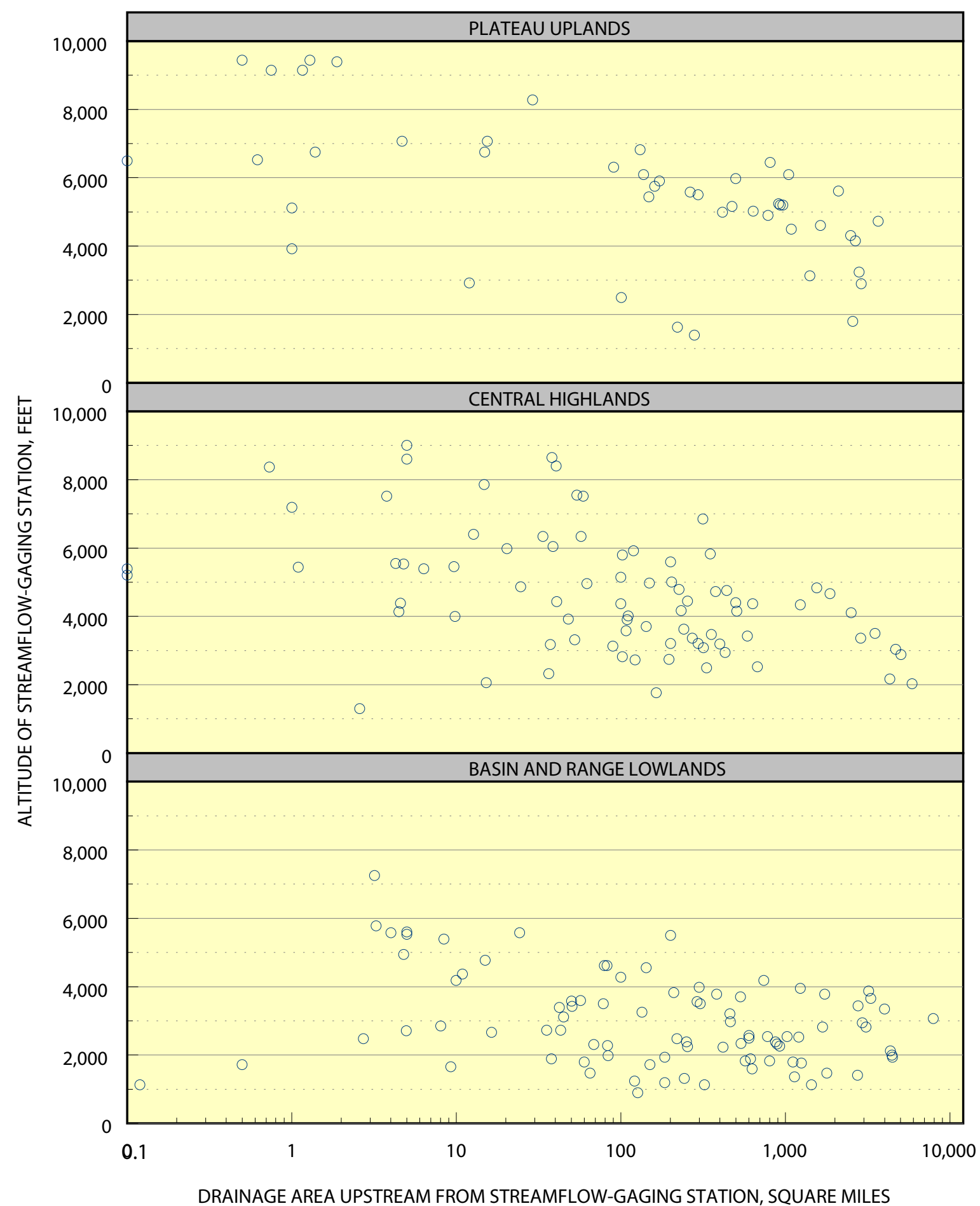

Figure 5. Distribution of altitude and drainage area for streamflow-gaging stations in the Plateau Uplands, Central Highlands, and Basin and Range Lowlands hydrologic provinces.

\section{Model Development}

The hydrological regime models were developed using tree-based methods, more specifically, classification trees. The advantages of tree-based models over linear and 
additive models are summarized by Insightful Corporation (2001): (1) they are easier to interpret when explanatory variables are a mix of numeric and factor variables, (2) they are invariant to monotone transformations of explanatory variables, such as log transformations or use of power functions, (3) they more satisfactorily treat missing values, (4) they are more adept at capturing nonadditive structure, (5) they allow more general interactions between predictor variables, and (6) they can easily model factor response variables with more than two levels.

In the tree-based methods, the model space is split into multiple regions using a set of recursive-binary partition rules. Consider, for example, a categorical response variable $Y$ and dependent variables $X_{1}$ and $X_{2}$. The model space defined by $X_{1}$ and $X_{2}$ is first split into two regions at $X_{1}=t_{1}$ (fig. $6 A$ ). As a result of splitting the model space, responses of $\mathrm{Y}$ are more homogeneous in each of the two resulting regions than in the unpartitioned model space. Next, one or both of these regions is further split into two or more regions, and this process is continued until a stopping point is determined. The resulting model space consists of multiple regions defined by $t_{1}, t_{2 \ldots} t_{\mathrm{n}}$. The models are called "classification trees" because of the tree-like appearance when the recursive binary splits are diagramed (fig. $6 B$ ). Models with three or more explanatory variables work in the same manner as that described here, but are more difficult to draw and visualize.

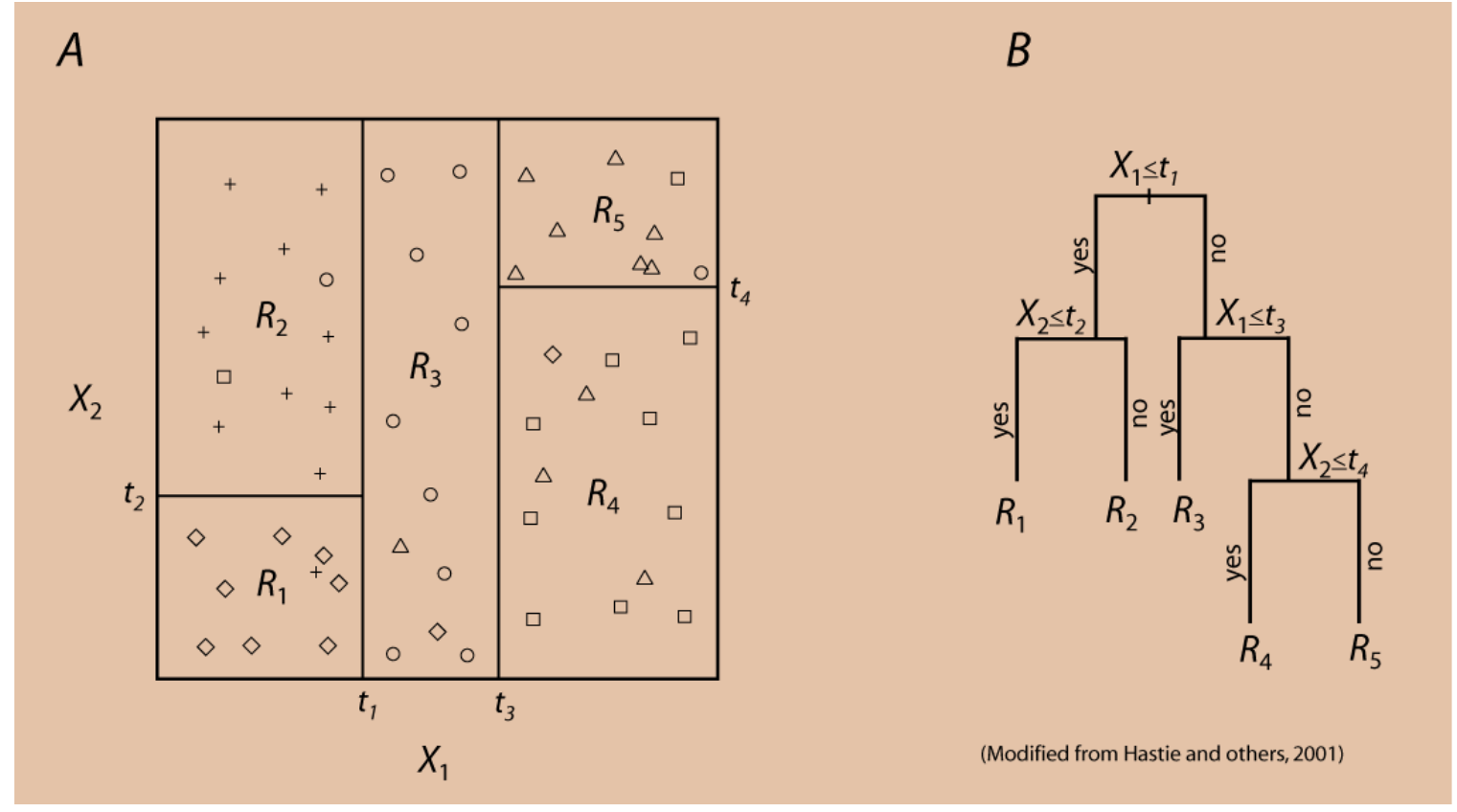

Figure 6. Example of recursive binary partitioning. $A$, shown geometrically; $B$, shown as a classification tree.

The statistical nature of the classification-tree type models is rooted in the algorithm used to grow and prune the tree. Statistical software (Insightful Corporation, 2002) was used to build the classification tree models. In the algorithm used by the software, the splitting variables chosen at each split $\left(\mathrm{X}_{1}, \mathrm{X}_{2}, \ldots \mathrm{X}_{\mathrm{n}}\right)$ and splitting values $\left(t_{1}, t_{2}, \ldots t_{n}\right)$ are recursively determined in a manner so as to minimize heterogeneity of response values in each region of the model space. Conceptually, sufficient splits could be included in the model so that each and every resulting region contains observations of exactly the same response of $Y$. A model such as this, however, would overfit the data in 
most cases. On the other hand, such classification trees should have enough splits to capture important structural relations between the response and the explanatory variables.

The modeling approach used in this study was to grow a large classification tree with a sufficient number of regions that (1) the response value of the observations was homogeneous within a region or (2) the number of observations remaining in a region was equal to a preset minimum value. The resulting initial classification tree is an overfit model; however, it contains the complete set of all possible splits that could be considered in the model. The next step is to prune the initial classification tree by sequentially removing splits from the tree. Determination of which splits to remove is based on the heterogeneity in the response values of the observations that is removed by each split.

The deviance is a measure of the heterogeneity of response values. For categorical-type response variables, the deviance for an observation is assigned as 0 if its value equals the predicted value, or it is assigned as 1 if its value differs from the predicted value. The total deviance of predicted values for a region is computed as the sum of the squared deviances for observations in the region. The residual deviance is the sum of the squared deviances for all observations in all regions of the model space. The residual mean deviance is a measure of the heterogeneity in the response variable that remains unaccounted for by the classification tree model, and is computed as the residual deviance divided by the degrees of freedom in the model, which in turn is computed as the number of observations minus the number of regions included in the model.

Cost-complexity pruning is an algorithm that removes the least important splits from a fully developed tree and results in a prespecified number of total regions (Hastie and others, 2001; Insightful Corporation, 2001). This algorithm was used by starting with 2 specified regions and examining the spitting rules and the deviance for the resulting regions. This process was performed iteratively by incrementing the number of regions by one and then examining the resulting splitting rules and deviances. The final model was selected on the basis of (1) the amount of the residual mean deviance that was reduced by adding one more region to the model (fig. 7) and (2) whether the additional splits resulted in an overfit model, as determined using professional hydrologic judgment. 

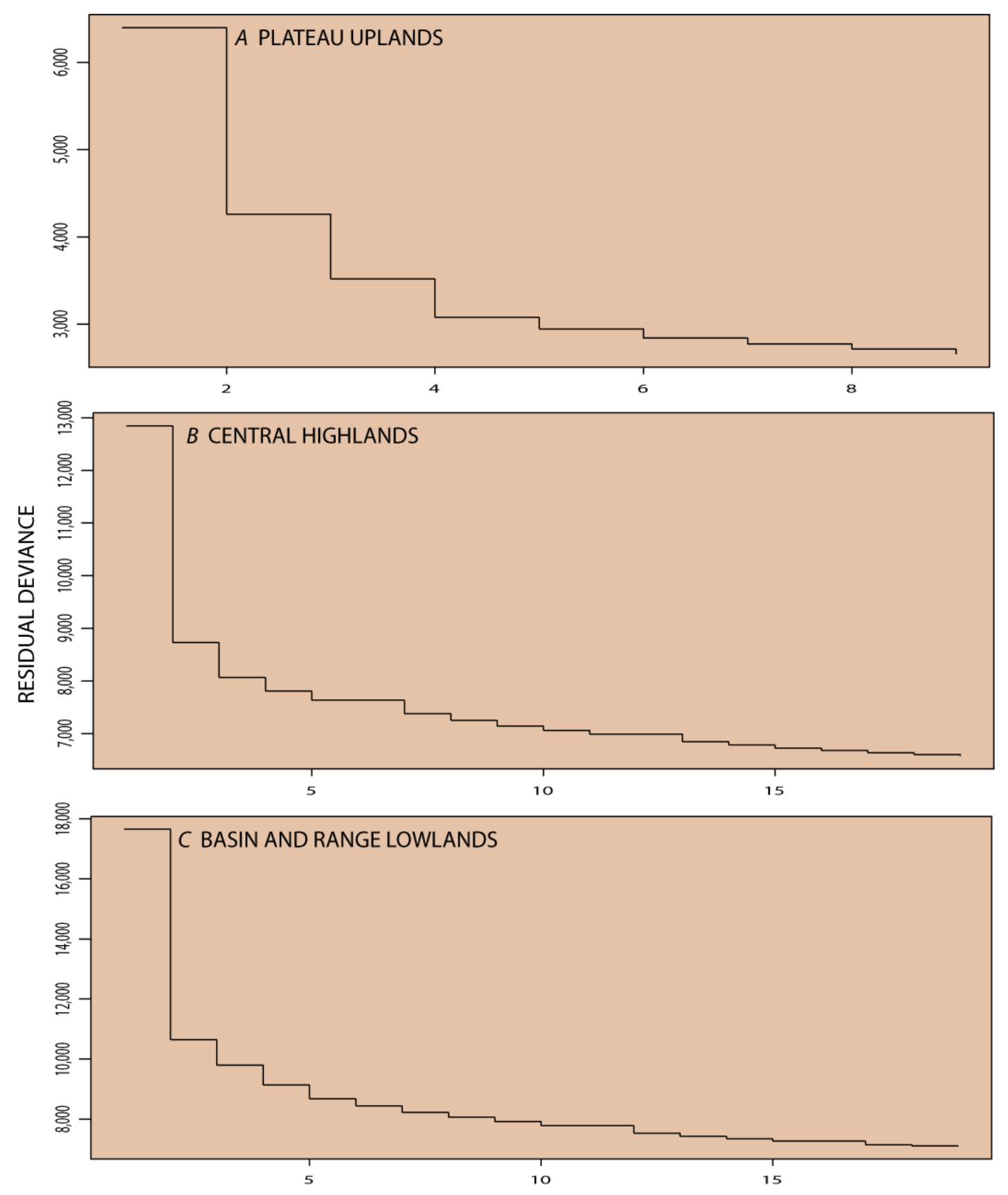

NUMBER OF REGIONS IN CLASSIFICATION TREE MODEL

Figure 7. Residual deviance as a function of the number of regions in the hydrological regime classification tree for models determined using cost-complexity pruning for $A$, the Plateau Uplands, $B$, the Central Highlands, and $C$, the Basin and Range Lowlands hydrologic provinces.

A single classification tree was developed for each of the three hydrogeologic provinces. The hydrological regime of streamflow was the response variable and had categorical values of perennial, nearly perennial, weakly perennial, and nonperennial. The classification tree was developed on the basis of explanatory values of reach discharge, month (season) of the reach discharge, climate index for the reach discharge, 
drainage area for the streamflow-gaging station, and altitude of the streamflow-gaging station. The resulting classification tree models for each hydrogeologic province are described in the next section.

\section{Statistical Models for Predicting Hydrological Regime}

The classification tree models for the three different hydrologic provinces contain five splits and result in six classified regions (figs. 8-10). Reach discharge was the single most important explanatory variable in all three models, as shown by the length of vertical lines in the classification tree diagrams (figs. 8-10) for splits that utilize reach discharge. This explanatory variable occurs in the first split and reduces the deviance more than all the other variables combined. The importance of reach discharge in these models for predicting hydrologic regime has a significant implication for other modeling efforts - any attempts to model and predict the hydrological regime of stream reaches in Arizona without utilizing some observation of discharge will likely result in much less reliable predictions than those presented in this study.

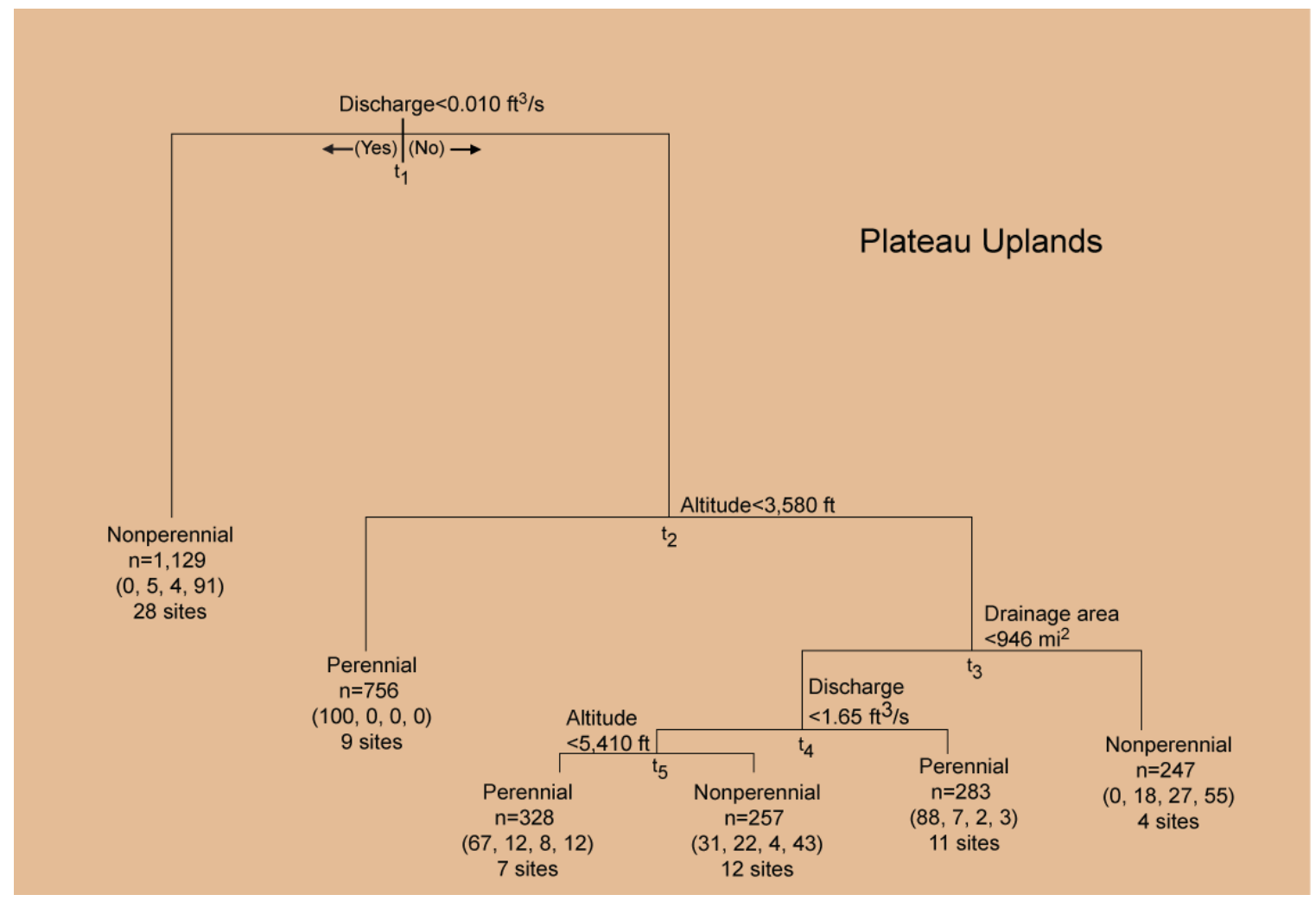

Figure 8. Hydrological regime classification tree for stream reaches in the Plateau Uplands hydrologic province. 


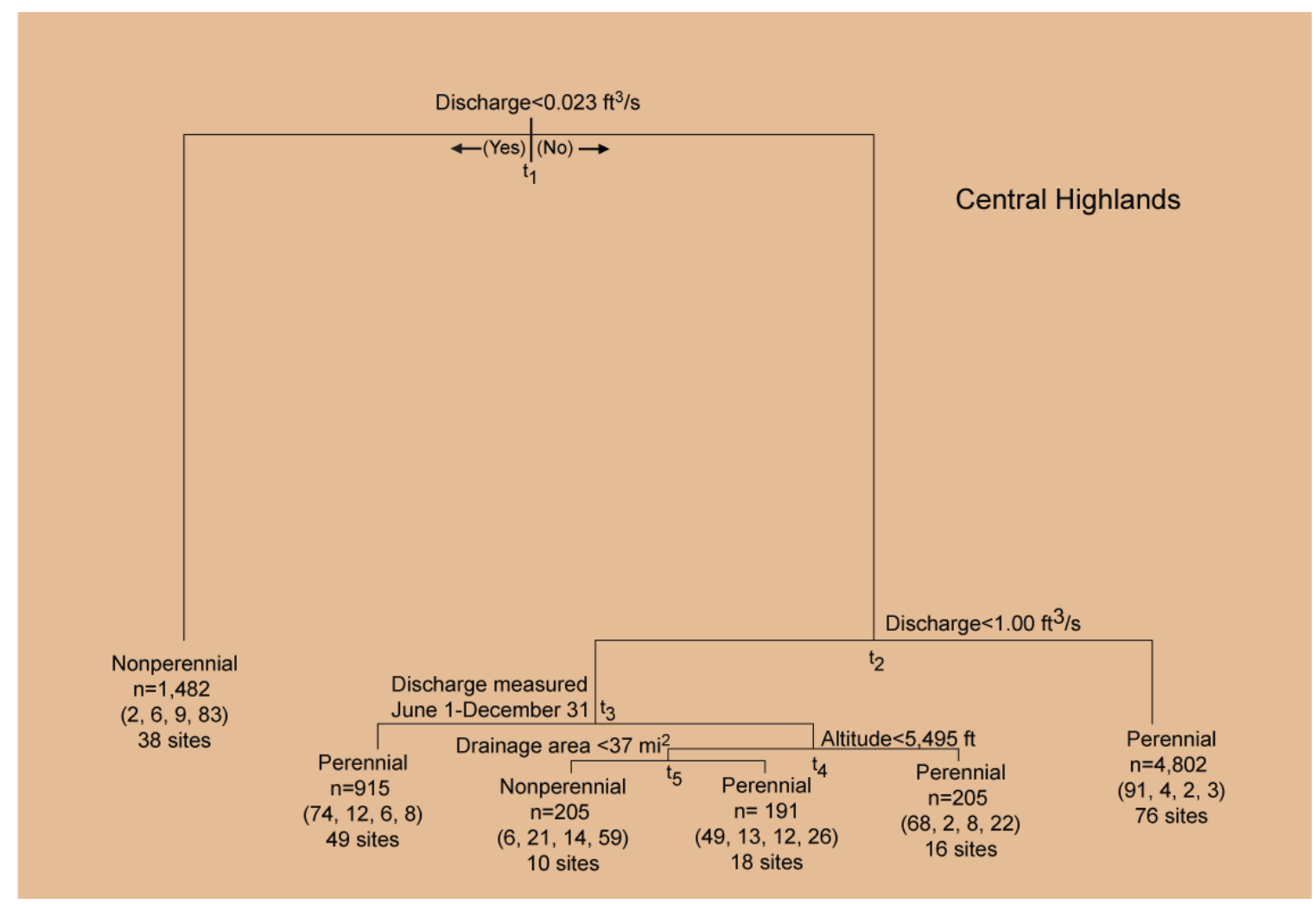

Figure 9. Hydrological regime classification tree for stream reaches in the Central Highlands hydrologic province. 


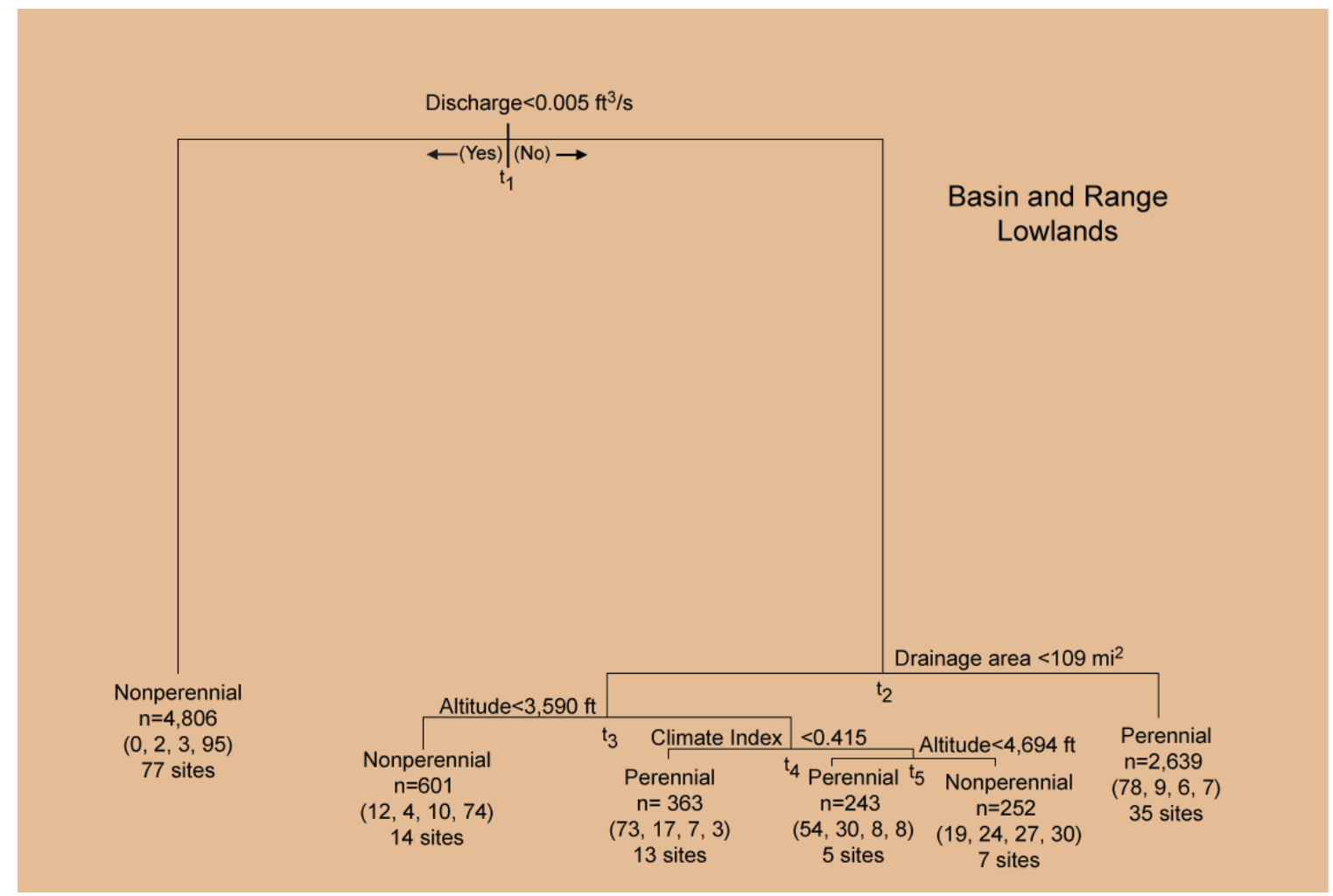

Figure 10. Hydrological regime classification tree for stream reaches in the Basin and Range Lowlands hydrologic province.

In each model, the first split essentially separates the observations with no measurable flow from those with measurable flow (figs. 8-10). Observations with no flow are classified as nonperennial. For observations which do in fact have flow, the models then continue to sort out the different hydrological regime classes on the basis of the remaining explanatory variables. In some cases, reach discharge is again a variable used to make a split in the classification tree. Other explanatory variables common to all three models included altitude and drainage area for the site. Month of the discharge measurement was only important for the Central Highlands model, and climate index was only important in the Basin and Range Lowlands model.

Each region is classified by the model as one of the four possible hydrological regime categories. For a given region, the category with the highest percentage of calibration observations is the predicted class for that region. Some regions were very homogeneous, having high percentages of calibration observations for one class and low percentages of other classes. For example, in the region classified as nonperennial by split $t_{1}$ in the Plateau Uplands model, 91 percent of the calibration observations were nonperennial, and 9 percent were in one of the other classes (fig. 8). Other regions classified by the model were not as homogenous. For example, in the region classified as nonperennial by split $t_{5}$ in the Plateau Uplands model, only 43 percent of the observations were nonperennial, while 31 percent were perennial, 22 percent were nearly perennial, and 4 percent were weakly perennial (fig. 8). For regions where the calibration observations are homogenous, model predictions are less likely to be misclassified, and conversely, where the classes of the calibration observations are heterogeneous, model predictions are more likely to be misclassified. 


\section{Plateau Uplands}

The classification tree for the Plateau Uplands hydrologic province contains six regions defined by five splits (fig. 8). Three of the regions are classified as perennial, and three are classified as nonperennial. Reaches classified as nonperennial as a result of split $t_{1}$ and those classified as perennial as a result of splits $t_{2}$ or $t_{4}$ have low misclassification rates; reaches classified into the remaining three regions have higher misclassification rates. Deviance in the observations was reduced from 6,398 without the model to 2,842 with the model, which indicates that the model accounts for about 56 percent of the variability in the observations.

Stream reaches classified as nonperennial as a result of $t_{1}$ were observed to have essentially no flow and can occur throughout the hydrologic province. Stream reaches classified into any of the remaining five regions have measurable flow. Stream reaches classified as perennial as a result of $\mathrm{t}_{2}$ occur at lower altitudes in the Grand Canyon. Stream reaches classified as nonperennial as a result of $t_{3}$ generally occur on the Little Colorado River above the Grand Canyon and on the downstream parts of the larger tributaries to the Little Colorado River. Splits $t_{4}$ and $t_{5}$ mostly classify reaches that occur on the more upstream parts of the larger tributaries to the Little Colorado River. Those with a discharge greater than $1.65 \mathrm{ft}^{3} / \mathrm{s}$ are classified as perennial. For those with a smaller discharge than this, only the reaches less than $5,410 \mathrm{ft}$ in altitude are classified as perennial. Those reaches above this altitude with a discharge less than $1.65 \mathrm{ft}^{3} / \mathrm{s}$ are classified as nonperennial and occur at higher altitudes in areas such as the Mogollon Rim, Black Mesa, and Defiance Plateau.

\section{Central Highlands}

The classification tree for the Central Highlands hydrologic province contains six regions defined by five splits (fig. 9). Four of the regions are classified as perennial, and two are classified as nonperennial. Reaches classified as nonperennial as a result of split $t_{1}$ and those classified as perennial as a result of split $t_{2}$ have low misclassification rates; reaches classified into the remaining regions have higher misclassification rates.

Deviation in the observations was reduced from 13,960 without the model to 8,363 with the model, which indicates that the model accounts for about 40 percent of the variability in the observations.

Stream reaches classified as nonperennial as a result of $t_{1}$ were observed to have essentially no flow and can occur throughout the hydrologic province. Stream reaches classified into any of the remaining five regions had measurable flow. For those with discharge greater than $1.00 \mathrm{ft}^{3} / \mathrm{s}$, they are classified as perennial. For the remaining reaches with discharges less than $1.00 \mathrm{ft}^{3} / \mathrm{s}$, their classification as perennial or nonperennial is dependent on the timing of the measurement and the altitude and drainage area for the reach. Reaches with a small discharge $\left(0.023\right.$ to $\left.1.00 \mathrm{ft}^{3} / \mathrm{s}\right)$ are classified as perennial if the measurement was collected between June 1 and December 31. This period represents the part of the year that typically does not receive snowmelt; therefore, the discharge is more likely to represent groundwater discharge, which is typically longer lived than snowmelt. For those reaches with a small discharge $(0.023$ to $1.00 \mathrm{ft}^{3} / \mathrm{s}$ ) measured between January 1 and June 1, only the reaches at lower altitudes (less than 5,495 ft) and small drainage areas (less than $37 \mathrm{mi}^{2}$ ) are classified as nonperennial. The reaches with a small discharge $\left(0.023\right.$ to $\left.1.00 \mathrm{ft}^{3} / \mathrm{s}\right)$ measured between January 1 and June 1 at higher altitudes (more than 5,495 ft) are classified as perennial, 
those measured with similar conditions at lower altitudes (less than 5,495 ft) in larger basins (greater than $37 \mathrm{mi}^{2}$ ) are also classified as perennial.

\section{Basin and Range Lowlands}

The classification tree for the Basin and Range Lowlands hydrologic province contains six regions defined by five splits (fig. 10). Three of the regions are classified as perennial, and three are classified as nonperennial. Reaches classified as nonperennial as a result of split $t_{1}$ and $t_{2}$ have low misclassification rates as indicated by the class percentages in these regions (fig. 10); reaches classified into the remaining regions have higher misclassification rates. Deviation in the observations was reduced from 17,660 without the model to 8,895 with the model, which indicates that the model accounts for about 50 percent of the variability in the observations.

Stream reaches classified as nonperennial as a result of $t_{1}$ were observed to have essentially no flow and can occur throughout the hydrologic province. Stream reaches classified into any of the remaining five regions have measurable flow (equal to or greater than $0.005 \mathrm{ft}^{3} / \mathrm{s}$ ). Reaches with drainage areas greater than $109 \mathrm{mi}^{2}$ and measurable flow are classified as perennial; reaches smaller than this are classified on the basis of altitude and climate index. Reaches with measurable flow on small drainages (less than $109 \mathrm{mi}^{2}$ ) are classified as nonperennial if the altitude is lower than 3,590 $\mathrm{ft}$. Most of the reaches below 3,590 ft occur in the valley bottoms throughout the province or in the mountains that occur in the southwestern part of the hydrologic province. Reaches on small drainages (less than $109 \mathrm{mi}^{2}$ ) at higher altitudes (greater than 3,590 ft) generally occur in the mountains in the southeastern or northwestern part of this hydrologic province. If discharge is measurable, these reaches are classified as perennial if it was a relatively wet year (climate index less than 0.42 ) when the measurement was collected. If, on the other hand, the measurement was collected during a normal or dry year (climate index greater than 0.42 ) in these mountain reaches, then it was classified as nonperennial if at an altitude higher than $4,694 \mathrm{ft}$; otherwise it was classified as perennial.

\section{Model Limitations and Topics for Additional Investigation}

The classification tree models (figs. 8-10) were developed for use by EMAP to reduce project resource expenditures associated with selecting apparent perennial stream reaches for aquatic ecology sampling that are later discovered during field work to in fact be nonperennial. The models were not developed for recreational purposes such as hiking or fishing, which desire perennial drinking water sources or aquatic habitat, nor were the models developed for legal establishment of water rights or regulation.

In general, a significant objective of developing regional-scale models is to apply them and obtain predictions throughout the study area. A clear limitation to the models developed in this study is the requirement of having discharge measurements to obtain hydrologic regime predictions. This precludes immediate statewide application of the model to all non-regulated reaches in Arizona because only a small number of sites (696 in this study) have discharge measurements. While further research is needed to develop models that predict hydrologic regime independent of discharge measurements, the fact that this study found discharge measurements to be more important than all the basin characteristics combined does not favor an optimistic view for developing such models.

For model predictions, input data values should be within the range of data used to calibrate the models. For example, the altitude and drainage area for prediction sites 
should be within the range for sites in the calibration data set (fig 5). Where input data for model predictions fall outside the range of the calibration data, model predictions will be less accurate because the model was not calibrated to those conditions, and skepticism of predicted values is warranted. Other conditions for the input data set include that the reach be unregulated and that discharge data have been collected between 1950 and 2005 .

The model accuracy was partially assessed on the basis of misclassification rates for the calibration data and is described here, followed by a discussion of other factors that likely lead to additional, nonassessed uncertainties for model predictions. Misclassification rates computed for all observations used to calibrate each model provide an overall measure of the model's performance in distinguishing hydrological regime classes. Total percentages of misclassified observations used to calibrate each model were 17 percent for the Plateau Uplands, 15 percent for the Central Highlands, and 14 percent for the Basin and Range Lowlands models (table 1). True misclassification rates are likely to be higher than those reported (table 1) because of the nonassessed uncertainties from other factors discussed below. 
Table 1. Misclassification matrices for the Plateau Uplands, Central Highlands, and Basin and Range Lowlands hydrological regime classification tree models.

[Units are percent of total observations; cases where observations are misclassified are shaded gray. Misclassification rates were determined from model calibration only and not determined from an independent data set.]

\begin{tabular}{|c|c|c|c|c|}
\hline \multirow{3}{*}{$\begin{array}{c}\text { Observed } \\
\begin{array}{c}\text { hydrological } \\
\text { regime }\end{array} \\
\end{array}$} & \multicolumn{4}{|c|}{ Plateau Uplands - 3,000 observations } \\
\hline & & Predicted $\mathrm{r}$ & drological & \\
\hline & Perennial & $\begin{array}{l}\text { Nearly } \\
\text { perennial }\end{array}$ & $\begin{array}{l}\text { Weakly } \\
\text { perennial }\end{array}$ & Nonperennial \\
\hline Perennial & 41 & 0 & 0 & 3 \\
\hline $\begin{array}{l}\text { Nearly } \\
\text { perennial }\end{array}$ & 2 & 0 & 0 & 5 \\
\hline $\begin{array}{l}\text { Weakly } \\
\text { perennial }\end{array}$ & 1 & 0 & 0 & 4 \\
\hline Nonperennial & 2 & 0 & 0 & 42 \\
\hline
\end{tabular}

\begin{tabular}{l|l|c|c|c|}
\multicolumn{1}{c}{$\begin{array}{c}\text { Observed } \\
\text { hydrological } \\
\text { regime }\end{array}$} & Perennial & $\begin{array}{l}\text { Nearly } \\
\text { perennial }\end{array}$ & $\begin{array}{l}\text { Weakly } \\
\text { perennial }\end{array}$ & Nonperennial \\
\cline { 2 - 5 } & Predicted hydrological regime \\
\hline Perennial & 68 & 0 & 0 & 1 \\
\hline $\begin{array}{l}\text { Nearly } \\
\text { perennial }\end{array}$ & 4 & 0 & 0 & 2 \\
\hline $\begin{array}{l}\text { Weakly } \\
\text { perennial }\end{array}$ & 2 & 0 & 0 & 2 \\
\hline Nonperennial & 4 & 0 & 0 & 17 \\
\hline
\end{tabular}

\begin{tabular}{|c|c|c|c|c|}
\hline \multirow{3}{*}{$\begin{array}{c}\text { Bas } \\
\text { Observed } \\
\begin{array}{c}\text { hydrological } \\
\text { regime }\end{array}\end{array}$} & \multirow{2}{*}{\multicolumn{4}{|c|}{$\begin{array}{l}\text { Lowlands }-8,904 \text { observations } \\
\text { Predicted hydrological regime }\end{array}$}} \\
\hline & & & & \\
\hline & Perennial & $\begin{array}{l}\text { Nearly } \\
\text { perennial }\end{array}$ & $\begin{array}{l}\text { Weakly } \\
\text { perennial }\end{array}$ & Nonperennial \\
\hline Perennial & 28 & 0 & 0 & 1 \\
\hline $\begin{array}{l}\text { Nearly } \\
\text { perennial }\end{array}$ & 4 & 0 & 0 & 2 \\
\hline $\begin{array}{l}\text { Weakly } \\
\text { perennial }\end{array}$ & 2 & 0 & 0 & 3 \\
\hline Nonperennial & 2 & 0 & 0 & 57 \\
\hline
\end{tabular}

Application of the hydrological regime models (figs 8-10) with the miscellaneous discharge measurements requires an assumption about the discharge for the reach and, as a result, increases the uncertainty of the predicted regime. The hydrological regime models were calibrated using monthly minimum daily discharge data; however, in this application of the model, an instantaneous discharge value collected during times without runoff was used. Although this discharge represents low flow conditions, it can only be 
equal to or greater than the actual monthly minimum daily discharge for the site. Conversely, the monthly minimum daily discharge for the site must be equal to or less than the observed discharge for the miscellaneous measurement. The nature of the classification tree, however, is somewhat forgiving about use of exact discharge data. Specifically, the predicted hydrologic regime for a given measurement at a site will only be misclassified as a result of the discharge-value substitution if the actual monthly minimum daily discharge for the site is less than the threshold values for discharge in the models $\left(0.010\right.$ and $1.65 \mathrm{ft}^{3} / \mathrm{s}, 0.023$ and $1.00 \mathrm{ft}^{3} / \mathrm{s}$, and $0.005 \mathrm{ft}^{3} / \mathrm{s}$ in figs. 8,9 , and 10 , respectively). This potential for misclassification is not accounted for in the values reported in table 1, so for this application of the model, uncertainties in the model predictions are higher than those reported in table 1.

The classification tree models are simple mathematical representations of the complex real world and are sensitive to data used for calibration. Biases in the calibration data, therefore, can lead to biased predictions. Most of the USGS streamflow-gaging stations used to calibrate the models typically were operated to obtain data on streams that are important drinking water or irrigation water supplies or aquatic, riparian, or wildlife habitat. The gages tend to be lower in the river basin, where drainage areas are larger and where flow is perennial. Consequently, smaller contributing drainages less than $10 \mathrm{mi}^{2}$ are less represented in the calibration data set (fig. 5), even though their occurrence in each hydrologic province is more common than the reaches with larger drainages. As an example of bias towards perennial streams, note that for the Plateau Uplands model, all of the data for the region left of split $t_{2}$ (less than 3,580 $\mathrm{ft}$ in altitude) were for gages on perennial reaches in the Grand Canyon; there were no nonperennial streams monitored. This bias in monitoring locations creates a zero-percent misclassification rate for that region of the model, effectively lowering the overall misclassification rate for the model.

The classification tree models and their predictions may contain bias due to the gages and data used in the calibration data set. For example, models may be sensitive to the years randomly selected for each gage-would the models (figs 8-10) be different if a different set of years for each gage were selected? Also, the models may be sensitive to the maximum number of years of data from each gage used for calibration-would the models (figs. 8-10) be different if only 5 years per gage was used instead of 10 years? What if a different set of gages was used for calibration? The sensitivity of the models to the selected gages and years was not evaluated.

All three models contain regions classified as either perennial or nonperennial streams. None of the three models, however, contained nearly perennial or weakly perennial class streams. The lack of distinguishing nearly or weakly perennial from perennial and non perennial streams may result from one or both of the following causes: (1) the small number of observations for these classes compared to the other two classes in the calibration data set, which can be observed in figure 2, (2) the explanatory variables used in the models are not sufficient for distinguishing these classes; perhaps other variables exist that could be used in the models to achieve this distinction. While the nearly perennial and weakly perennial classes were not effective in the model, they were kept because of their potential importance to developing aquatic biological monitoring plans and important to ADEQ. The effect of recoding the calibration data to just two hydrologic regime classes - perennial and nonperennial - and then recalibrating the models, was not evaluated. Misclassification results from the model calibration (table 1) indicate that reaches observed as nearly perennial or weakly perennial may be 
misclassified by the model as either perennial or nonperennial, with no clear tendency to misclassify strictly to one or the other class.

There is potential to improve the models through evaluation of the potential biases in the models due to factors described above, as well as incorporating other input data from sources such as aerial photography or satellite images. Areas with lush riparian vegetation are more likely to be perennial, and those lacking vegetation are more likely to be nonperennial. The model may also be improved by considering hydrologic regimes for upstream or downstream reaches. For example, a particular reach should have a higher probability of being perennial if the reach upstream from it is perennial. One of the most important areas for model improvement is the accuracy estimates. A set of reaches independent of those used in the calibration data set could be monitored, and the hydrologic regime determined from field data could be compared to that predicted by the model, resulting in a true set of misclassification estimates. This method of assessing the model accuracy would also account for the uncertainty that is propagated into the results when the hydrologic regime is determined from multiple discharge measurements, a topic described in the following section.

\section{Application of Hydrological Regime Models for Sites with Miscellaneous Discharge Measurement Data}

The database of miscellaneous discharge measurements includes about 12,000 measurements collected between 1947 and 2005 by ADEQ and its predecessor agency, the water quality section of the State Department of Health. Measurements for sites downstream from major reservoirs and sites on canals, diversions, and streams on which flow is maintained by effluent or irrigation return flow were removed from this data set because the model was not calibrated to predict hydrological regime for these conditions. To keep conditions for prediction sites and measurements similar to those used to calibrate the model, measurements before 1955, and measurements for sites with altitudes or drainage areas substantially larger or smaller than those represented in the calibration data set, were removed from the analysis. Measurements were also removed from the analysis where the discharge value clearly indicated runoff conditions, generally greater than $100 \mathrm{ft}^{3} / \mathrm{sec}$. The resulting dataset contained 5,080 discharge measurements at 696 sites that were used for predictive purposes in this study (fig. 11). Of these sites, 146 with a total of 1,122 measurements were in the Plateau Uplands, 341 with 2,333 measurements were in the Central Highlands, and 209 with 1,625 measurements were in the Basin and Range Lowlands. The ADEQ database contains altitude and drainage area for most sites. Where altitude data were missing, altitude was estimated from topographic maps to the nearest 10 feet. Missing drainage areas were estimated as being above or below the threshold values in each of the three models (figs. 8-10). For example, sites in the Plateau Uplands province lacking drainage area data were estimated as being above or below the threshold values of 946 square miles (fig. 8). A variety of sources were used to estimate missing drainage area values above or below the thresholds for each province (figs. 8$10)$. 


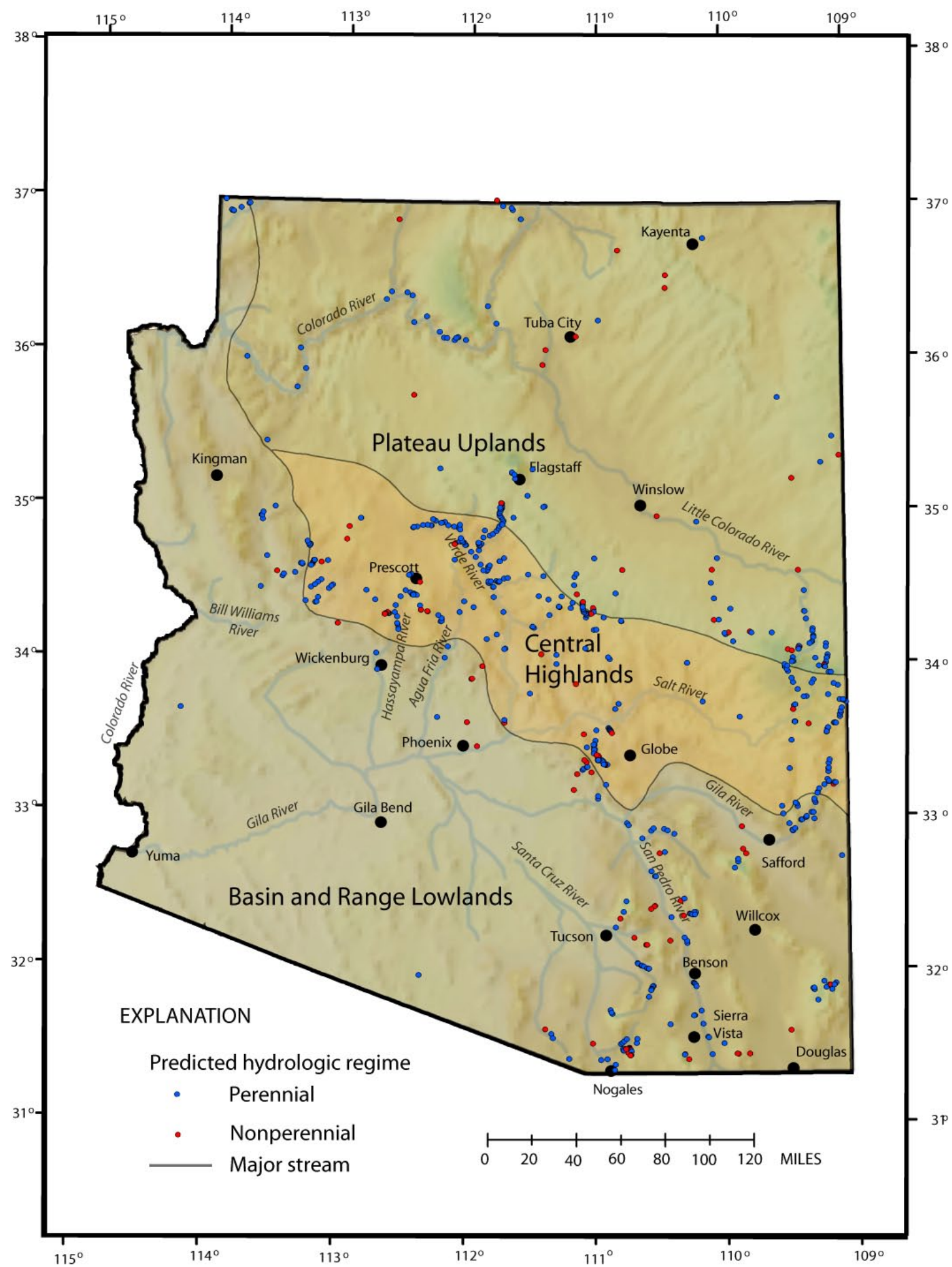

Figure 11. Predicted hydrological regime for sites with miscellaneous discharge measurement data available from the Arizona Department of Environmental Quality. 
The method for predicting hydrological regime for sites with ADEQ miscellaneous discharge measurement data can be best illustrated by walking through the models with several examples. In each model, the first decision to be made is whether the measurement exceeds a threshold discharge of $0.010 \mathrm{ft}^{3} / \mathrm{s}$ for Plateau Uplands sites, $0.023 \mathrm{ft}^{3} / \mathrm{s}$ for Central Highlands sites, and $0.005 \mathrm{ft}^{3} / \mathrm{s}$ Basin and Range sites. According to calibrated models (figs. 8-10), a site where all measurements are below the threshold for the province in which that site is located will be classified as nonperennial and no further tests are required to classify that reach. There are, however, small probabilities that a stream site in that category might, in fact, be other than nonperennial. In the Plateau Uplands, a site with a measured discharge of less than $0.010 \mathrm{ft}^{3} / \mathrm{s}$ has a 5-percent chance of being nearly perennial and a 4-percent chance of being weakly perennial (fig. 8); in the Basin and Range province there is a 2-percent and 3-percent chance that a site falls within those respective categories (fig. 10). In the Central Highlands province, a site with a single measured discharge of less than $0.023 \mathrm{ft}^{3} / \mathrm{s}$ has a 2-percent chance of being perennial, a 6-percent chance of being nearly perennial and a 9-percent chance of being weakly perennial (fig. 9).

More typically, sites have multiple measurements that may be above and below the threshold discharges for the province. For example, the ADEQ site SPSPR005.28 (appendix 2, row 638) has a record of 18 discharge measurements, 3 of which are zero; the remaining 15 measurements range from $0.57 \mathrm{ft}^{3} / \mathrm{s}$ to $54 \mathrm{ft}^{3} / \mathrm{s}$ (appendix 3, rows 4,4514,468). The site is located in the Basin and Range province, so the initial test of each measurement is whether the discharge is under the threshold value of $0.005 \mathrm{ft}^{3} / \mathrm{s}$ (fig. 10). The three measurements with zero discharge are moved to the left at split $t_{1}$ and assigned to the nonperennial category although there is a 2-percent chance that the measurements represent nearly perennial conditions and a 3-percent chance that the measurements represent weakly perennial conditions. The 15 other discharge measurements are all above the threshold discharge value and are moved toward the right at split $\mathrm{t}_{1}$; the watershed above that stream reach has a drainage area greater than $109 \mathrm{mi}^{2}$, so the 15 measurements are moved to the right at split $t_{2}$ into the perennial category. The chance that those 15 measurements are in reaches that are, in fact, perennial is 78 percent; there is a 9-percent chance that the stream reach is nearly perennial, a 6-percent chance that the reach is weakly perennial and a 7-percent chance that it is nonperennial. For assessing the overall hydrologic regime of the site, the probability for each of the 4 different classes is taken as the average probability from all measurements. Other schemes could have been used to integrate the results from multiple measurements, such as weighted averaging; however, this approach was the most simple and treats every measurement equally. For ADEQ site SPSPR005.28, the average probability for each class as determined from the 18 discharge measurements is as follows: a 65-percent chance of being perennial, an 8percent chance of being nearly perennial, a 5-percent chance of being weakly perennial and a 22-percent chance of being nonperennial. The most likely hydrologic regime for the reach is perennial, and it is classified as such. (appendix 4, row 639).

Another example illustrates the process of carrying a miscellaneous discharge measurement through the lowest levels of the tree diagram. ADEQ site BWSMR026.08 in the Central Highlands (appendix 2, row 175; appendix 3, rows 1,293-1,323) has 31 discharge measurements. Of these measurements, three are less than $0.023 \mathrm{ft}^{3} / \mathrm{s}$ and are moved to the left at split $t_{1}$ where they are classified as nonperennial but have a 2-percent chance of being perennial, a 6-percent chance of being nearly perennial, a 9-percent chance of being weakly perennial and an 83-percent chance of being nonperennial (fig. 
9). Another 17 measurements are between $0.023 \mathrm{ft}^{3} / \mathrm{s}$ and $1.00 \mathrm{ft}^{3} / \mathrm{s}$, and at split $\mathrm{t}_{2}$ those measurements are moved left to split $t_{3}$ where the seasonality of the measurements is tested. Ten of the measurements were made from June 1 to December 31, and they are moved left to split $t_{3}$ and are classified as perennial with probabilities of 74 percent, 12 percent, 6 percent, and 8 percent for the four hydrological regime categories. The 7 measurements made from January 1 to May 31 are moved to the right, where they are tested for altitude at split $\mathrm{t}_{4}$. The altitude at the site is about $1,760 \mathrm{ft}$, so the measurements are moved to the left and subject to a test for drainage area at split $t_{5}$. Because the drainage area is greater than $37 \mathrm{mi}^{2}$, the measurements are moved to the right and are classified as perennial with probabilities of 49 percent, 13 percent, 12 percent, and 26 percent. Finally, the 11 discharge measurements that were greater than $1.00 \mathrm{ft}^{3} / \mathrm{s}$ at split $\mathrm{t}_{2}$ are moved to the right and are classified as perennial with probabilities of 91 percent, 4 percent, 2 percent and 3 percent. When the probabilities for the 31 measurements are averaged, the stream reach is classified as perennial with a 68-percent chance that the reach is perennial, a 9-percent chance that it is nearly perennial, a 6-percent chance that it is weakly perennial and a 17-percent chance that it is nonperennial (appendix 4, row 176).

A summary of hydrological regime predictions for sites with miscellaneous discharge measurement data from ADEQ shows that the Central Highlands has a higher percentage of sites that are perennial ( 87 percent) than the other two provinces. For sites that are classified as perennial, the average probabilities of each hydrological regime class are almost identical for the three hydrologic provinces (table 2). The prediction of the hydrological regime for Basin and Range sites shows a considerably lower average probability for that classification-72 percent as opposed to 80 and 81 percent for the other two provinces - with higher probabilities in the nearly perennial, weakly perennial, and nonperennial categories (table 2). Stream reaches that are classified as nonperennial in all three provinces show a generally higher level of uncertainty than those classified as perennial, as indicated by the 46-, 62-, and 60-percent average probabilities for those predicted as nonperennial (table 2).

Table 2. Summary of predictions for sites with miscellaneous discharge measurement data available from the Arizona Department of Environmental Quality.

\begin{tabular}{|c|c|c|c|c|c|c|c|c|c|c|}
\hline \multirow[b]{2}{*}{$\begin{array}{l}\text { Hydrologic } \\
\text { Province }\end{array}$} & \multicolumn{2}{|c|}{$\begin{array}{l}\text { Number of sites } \\
\text { classified (with percent } \\
\text { of total for province) }\end{array}$} & \multicolumn{4}{|c|}{$\begin{array}{c}\text { Average probability of each class for sites } \\
\text { classified as perennial }\end{array}$} & \multicolumn{4}{|c|}{$\begin{array}{l}\text { Average probability of each class for sites } \\
\text { classified as nonperennial }\end{array}$} \\
\hline & $\begin{array}{l}\text { Perennial } \\
(\mathrm{P})\end{array}$ & $\begin{array}{c}\text { Nonperennial } \\
\text { (NP3) }\end{array}$ & $\begin{array}{l}\text { Perennial } \\
(\mathrm{P})\end{array}$ & $\begin{array}{c}\text { Nearly } \\
\text { perennial } \\
(\mathrm{NP1})\end{array}$ & $\begin{array}{l}\text { Weakly } \\
\text { Perennial } \\
\text { (NP2) }\end{array}$ & $\begin{array}{l}\text { Nonperennia } \\
\text { I (NP3) }\end{array}$ & $\begin{array}{c}\text { Perennial } \\
(P)\end{array}$ & $\begin{array}{c}\text { Nearly } \\
\text { perennial } \\
\text { (NP1) }\end{array}$ & $\begin{array}{l}\text { Weakly } \\
\text { Perennial } \\
\text { (NP2) }\end{array}$ & $\begin{array}{l}\text { Nonperennial } \\
\text { (NP3) }\end{array}$ \\
\hline Plateau & & & & & & & & & & \\
\hline $\begin{array}{l}\text { Uplands } \\
\text { Central }\end{array}$ & $113(77 \%)$ & $33(23 \%)$ & $80 \%$ & $8 \%$ & $2 \%$ & $10 \%$ & $22 \%$ & $21 \%$ & $11 \%$ & $46 \%$ \\
\hline $\begin{array}{l}\text { Highlands } \\
\text { Basin and }\end{array}$ & $297(87 \%)$ & $44(13 \%)$ & $81 \%$ & $6 \%$ & $4 \%$ & $9 \%$ & $16 \%$ & $12 \%$ & $10 \%$ & $62 \%$ \\
\hline $\begin{array}{l}\text { Range } \\
\text { Lowlands }\end{array}$ & $159(76 \%)$ & $50(24 \%)$ & $72 \%$ & $12 \%$ & $7 \%$ & $9 \%$ & $16 \%$ & $10 \%$ & $14 \%$ & $60 \%$ \\
\hline
\end{tabular}

\section{Summary and Conclusions}

Three statistical models were developed to help predict the hydrological regime of stream reaches in Arizona. One model each was developed for the Plateau Uplands, the 
Central Highlands, and the Basin and Range Lowlands to roughly account for the hydrogeologic variability among the State. The model was calibrated with daily discharge data sampled from 218 USGS streamflow-gaging stations, including 3 stations in the Little Colorado River and upper Gila River drainages in New Mexico. Because the statistical models were to be used to predict hydrological regime from ADEQ miscellaneous discharge measurements, which are typically collected under low-flow conditions, the calibration data consisted of monthly minimum daily flow values that would be representative of the flow conditions for the ADEQ data. Other calibration data included the month in which the reach discharge was collected, a climate index indicating the relative precipitation level for the year of the reach discharge, reach altitude, and drainage area. For each complete year of data for each station used in the calibration, a reach was classified as being (1) perennial, which has no days of zero-discharge flow for the year of interest, (2) nearly perennial, which has zero-discharge flow on at least one day of the year, but not more than 10 percent of the year, (3) weakly perennial, which had zero-discharge flow between 10 and 20 percent of the year, or (4) nonperennial, which had zero-discharge flow more than 20 percent of the year.

The classification tree models (figs. 8-10) developed in this investigation performed reasonably well at predicting the hydrological regime of stream reaches in the calibration data set (table 1). In all three hydrologic provinces, the models performed best on stream reaches that were perennial or nonperennial (table 1). Misclassification of stream reaches occurred mainly on stream reaches that were either nearly perennial or weakly perennial. In the Plateau Uplands, 44 percent of the total observations were perennial. The model correctly classified 41 percent of the perennial observations and misclassified 3 percent of the perennial observations as nonperennial. The model also performed well on observations that were nonperennial. The model predicted that 42 percent of the observations were nonperennial and misclassified 2 percent of the observations as perennial. None of the observations that fell within the nearly perennial and weakly perennial categories, however, were classified correctly by the predictive model. Similar results were obtained with the Central Highlands and Basin and Range Lowlands models. Only 1 percent of the perennial observations from the Central Highlands and from Basin and Range Lowlands were misclassified as nonperennial. The models worked nearly as well with those stream reaches that were observed to be nonperennial but failed in both cases to correctly predict any of the nearly perennial or weakly perennial observations (table 1). The misclassification of the middle categories of hydrological regime may have been the result of having few stream reaches in those categories (table 1) or because there are other explanatory variable not used that might have better discriminated among those categories.

In all models, the most influential predictors of hydrological regime were at the first and second splits (figs. 8-10). For the calibration data sets, about 85 percent of all nonperennial classifications were made at the $t_{1}$ split if daily discharge values were below the threshold discharge for the particular model, and about 74 percent of all perennial classifications were made at the $t_{2}$ split, having exceeded the threshold discharge for the model and then undergoing a second test, which involved a different criterion for each model (percentages stated here are based on number of calibration observations and percentage of nonperennial observations shown in figs. 8-10).

The predictions of hydrological regime for the stream reaches in the ADEQ miscellaneous discharge measurement database appear reasonable in that they somewhat reflect the hydrologic variability to be expected in the state. A significant difference 
between the calibration data set and the predictions for the reaches in the ADEQ database is that most of the stream reaches in the Basin and Range are predicted to be perennial (table 2) as opposed to the calibration data (table 1); however, this probably is because ADEQ's monitoring program is aimed at collecting samples in perennial stream reaches. The models provided predictions of the hydrologic regime for 696 sites with miscellaneous discharge measurements from ADEQ, and the percentages of sites predicted as being perennial and nonperennial, respectively, were 77 and 23 for the Plateau Uplands, 87 and 13 for the Central Highlands, and 76 and 24 for the Basin and Range Lowlands provinces.

\section{References Cited}

Anderson, T.W., Freethey, G.W., and Tucci, P., 1992, Geohydrology and waters resources of alluvial basins in south-central Arizona and parts of adjacent states: U.S. Geological Survey Professional Paper 1406-B, 67 p, 3 sheets, scales $1: 1,000,000$.

Arizona State Land Department, 1969, Annual report on ground water in Arizona, spring 1967 to spring 1968: Phoenix, Arizona State Land Department Water-Resources Report 38, 54 p.

Arizona State Land Department, 1993, Streams - Ephemeral and Perennial: Phoenix, Arizona, Arizona State Land Department [http://www.land.state.az.us/alris/metadata/streams.htm accessed September 2, 2009].

Brown, D.E., Carmony, N.B., and Turner, R.M., compilers, 1981, Drainage map of Arizona showing perennial streams and some important wetlands: Phoenix, Arizona Game and Fish Department, 1 sheet, scale 1:1,000,000.

Giller, P.S. and Malmqvist, B., 1998, The biology of streams and rivers: New York, Oxford University Press, 296 p.

Hart, R.J., Ward, J.J., Bills, D.J. and Flynn, M.E., 2002, Generalized hydrogeology and ground-water budget for the $\mathrm{C}$ aquifer, Little Colorado River basin and parts of the Verde and Salt River basins, Arizona and New Mexico: USGS WaterResources Investigations Report 02-4026, 47 p.

Hastie, Trevor, Tibshirani, Robert, and Friedman, Jerome, 2001, The elements of statistical learning; data mining, inference, and prediction New York, SpringerVerlag, 533 p.

Insightful Corporation, 2001, S-Plus 6 for Windows guide to statistics, volume 2: Seattle, Washington, Insightful Corporation, $622 \mathrm{p}$.

Insightful Corporation, 2002, S-Plus 6.1 for Windows, professional edition, release 1: Seattle, Washington, Insightful Corporation, computer software.

Parker, J.T.C, Steinkampf, W.C., and Flynn, M.E., 2005, Hydrogeology of the Mogollon Highlands, central Arizona: U.S. Geological Survey Scientific Investigations Report 2004-5294, 87 p. [http://pubs.usgs.gov/sir/2004/5294/, accessed April 3, 2007].

Phillips, J.V., and Thomas, B.E., 2005, Hydrologic conditions in Arizona 1999-2004 a historical perspective: U.S. Geological Survey Fact Sheet 2005-3081, 4 p. [http://pubs.usgs.gov/fs/2005/3081/, accessed April 3, 2007] 
Robinson, A.T., Paretti, N.V., and Cordy, G.E., 2006, Ecological assessment of Arizona's streams and rivers, 2000-2004: Phoenix, Arizona Game and Fish Department, Research Branch, $52 \mathrm{p}$.

Seaber, P.R., Kapinos, P.F., and Knapp, G.L., 1987, Hydrologic unit maps: U.S. Geological Survey Water-Supply Paper 2294, 63 p., 1 sheet.

State of Arizona, 1996, Water quality standards: Phoenix, State of Arizona, Arizona Administrative Code, Title 18, Chap 11, p. 1-60.

United Nations Educational, Scientific and Cultural Organization, 2007, International Glossary of Hydrology

[http://webworld.unesco.org/water/ihp/db/glossary/glu/aglu.htm, accessed April 3, 2007].

United States Environmental Protection Agency, 2007, Environmental Monitoring and Assessment Program (EMAP) [http://www.epa.gov/emap/, accessed February 14, 2007].

United States Geological Survey, 1999a, The National Hydrography Data Set: U.S. Geological Survey Fact Sheet 106-99

[http://erg.usgs.gov/isb/pubs/factsheets/fs10699.html, accessed February 13, 2007].

United States Geological Survey, 1999b, Standards for National Hydrography Dataset (draft) [http://rockyweb.cr.usgs.gov/nmpstds/acrodocs/draft/dlgf/nhd/NHD0799.PDF p. 2-100, accessed February 13, 2007].

United States Geological Survey, 2006, USGS Digital Line Graph [http://eros.usgs.gov/guides/dlg.html\#dlg8, accessed February 14, 2007].

Williams, C.N., Jr., Menne, M.J., Vose, R.S, and Easterling, D.R., 2005, United States historical climatology network monthly temperature and precipitation data, ORNL/CDIAC-118, NDP-019: Oak Ridge, Tennessee, U.S. Department of Energy, Oak Ridge National Laboratory, Carbon Dioxide Information Analysis Center [http://cdiac.ornl.gov/epubs/ndp/ushcn/usa_monthly.html, accessed April $18-25,2006]$. 


\section{Appendixes}

Appendix 1. Summary of location, basin, and hydrological-regime characteristics for U.S. Geological Survey streamflow-gaging stations in Arizona and parts of adjacent states that were used to calibrate the hydrological-regime models,

http://pubs.usgs.gov/of/2009/1269/appendixes/appendixl/

Appendix 2. Summary of location and basin characteristics for sites at which discharge measurements are available from the Arizona Department of Environmental Quality.

http://pubs.usgs.gov/of/2009/1269/appendixes/appendix2/

Appendix 3. Model input and model predictions for hydrological regime of sites at which discharge measurements are available from the Arizona Department of Environmental Quality,

http://pubs.usgs.gov/of/2009/1269/appendixes/appendix3/

Appendix 4. Summary of model predictions for hydrological regime of sites at which discharge measurements are available from the Arizona Department of Environmental Quality,

http://pubs.usgs.gov/of/2009/1269/appendixes/appendix4/ 